\title{
Entry \\ CRISPR towards a Sustainable Agriculture
}

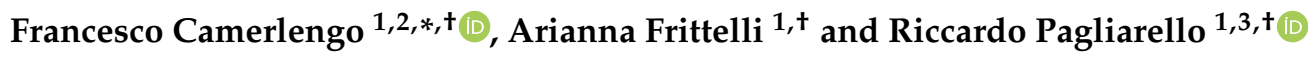 \\ 1 Department of Agriculture and Forest Sciences, University of Tuscia, 01100 Viterbo, Italy; \\ a.frittelli@unitus.it (A.F.); riccardo.pagliarello@enea.it (R.P.) \\ 2 USDA-ARS Western Wheat Quality Laboratory, Department of Crop and Soil Sciences, Washington State \\ University, Pullman, WA 99164, USA \\ 3 Department for Sustainability, Biotechnology and Agro-Industry Division-Biotec Laboratory, Italian National \\ Agency for New Technologies, Energy and Sustainable Economic Development, 00196 Rome, Italy \\ * Correspondence: f.camerlengo@unitus.it \\ + These authors contributed equally to this work.
}

Citation: Camerlengo, F.; Frittelli, A.; Pagliarello, R. CRISPR towards a

Sustainable Agriculture. Encyclopedia 2022, 2, 538-558. https://doi.org/

10.3390/encyclopedia2010036

Academic Editors: Andrea De Montis and Raffaele Barretta

Received: 27 November 2021

Accepted: 24 February 2022

Published: 28 February 2022

Publisher's Note: MDPI stays neutral with regard to jurisdictional claims in published maps and institutional affiliations.

Copyright: (c) 2022 by the authors. Licensee MDPI, Basel, Switzerland. This article is an open access article distributed under the terms and conditions of the Creative Commons Attribution (CC BY) license (https:// creativecommons.org/licenses/by/ $4.0 /)$.
Definition: Climate change and the need to feed an increasing population undermines food production and safety, representing the reasons behind the development of a new agriculture that is much more sustainable, productive and accessible worldwide. Genome editing and, in particular, clustered regularly interspaced palindromic repeats/CRISPR-associated protein (CRISPR/Cas) tools will play a major role in plant breeding to address these concerns. CRISPR/Cas includes a series of genome editing tools relying on the recognition and cleavage of target DNA/RNA sequences to introduce specific mutations.

Keywords: CRISPR; crop improvement; genetic variability; stress tolerance; food quality; synthetic biology; sustainable agriculture

\section{Introduction}

The term "sustainable agriculture" encloses practices of farming addressed to the production of high-quality and safe agricultural products without compromising natural environments and the social and economic conditions of farmers. According to the Agricultural Sustainability Institute at UC Davis (https:/ / www.nal.usda.gov/legacy/afsic/ sustainable-agriculture-definitions-and-terms, accessed on 10 January 2022), the main goal of sustainable agriculture remains the preservation of the ability of future generations to meet their own needs, ensuring inclusive economic growth.

In the era of climate change, environmental threats will affect farmers at both the economic and the agronomic level, influencing crop yield and quality and with further negative effects on plant resistance to both abiotic and biotic stress. In order to counteract these environmental threats, and to have the chance to reach a sustainable production of industrial manufacture, new technologies will be used on the basis of the current knowledge in the biotechnology field.

Clustered regularly interspaced palindromic repeats (CRISPR) and CRISPR-associated protein (Cas) represent a new perspective for genetic engineering and the last frontiers of the new breeding techniques (NBTs) and genome editing (GE) tools.

\subsection{CRISPR/Cas System}

CRISPR/Cas systems are part of the adaptative immune system of archaea and bacteria in ensuring protection against viruses. The mechanism of action relies on the recognition and the cleavage of foreign DNA or RNA of invading viruses. One of the main characteristics is the integration of short fragments of the invading DNA (spacers) into the CRISPR locus, conferring the heritable immunity of bacteria. The CRISPR locus consists of an array of unique spacer sequences, derived from foreign invading DNA and interspaced by identical repeat sequences (crisprRNA or crRNA), along with a sequence encoding for the 
trans-activating crRNA (tracrRNA) and a series of genes encoding CRISPR-associated (Cas) endonucleases, responsible for the cleavage of the genetic material. The transcription of the CRISPR locus allows for the formation of a single mRNA (pre-crRNA), which is partially complementary to tracrRNA, leading to the formation of an RNA duplex. The RNase III recognizes the RNA duplex and cleaves the double-stranded RNA (dsRNA) to form crRNA-tracrRNA complexes that activate and drive the Cas protein to the target sequence. The Cas protein is capable of introducing a double-strand break (DSB) only in the presence of a short conserved protospacer-adjacent motif (PAM) downstream of the target DNA, representing an essential prerequisite for the recognition of the target sequence [1,2].

CRISPR/Cas systems have been divided into two classes, six types and several subgroups based on Cas proteins and the nature of the interference complex [3]. To date, the most common type, used as a genome editing tool, is the Type II Cas9 from Streptococcus pyogenes ( $\mathrm{S} p \mathrm{Cas} 9$ ). The Cas9 protein consists of a bi-lobed architecture, including a large recognition (REC) lobe and a small nuclease (NUC) lobe. The NUC lobe includes a protospacer-adjacent motif (PAM)-interacting domain (PI) and two cleavage domains known as RuvC and $\mathrm{HNH}$ domains, each of which cleaves one strand of the target DNA three nucleotides upstream of the PAM sequence (Figure 1A) [4,5]. The REC lobe contributes toward activating Cas proteins when combined with the tracrRNA-crRNA complex.

A
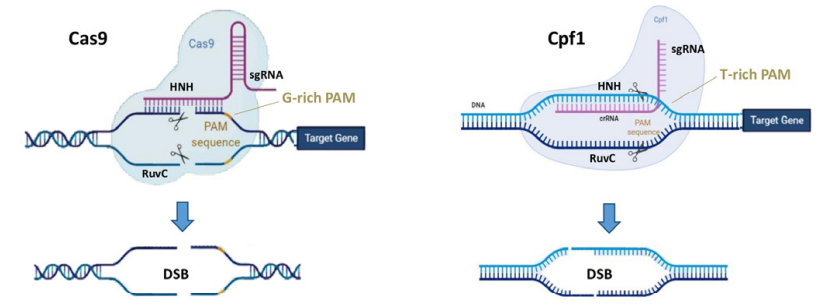

CRISPR/Cas9 or Cpf1 for gene knock-in/knock-out

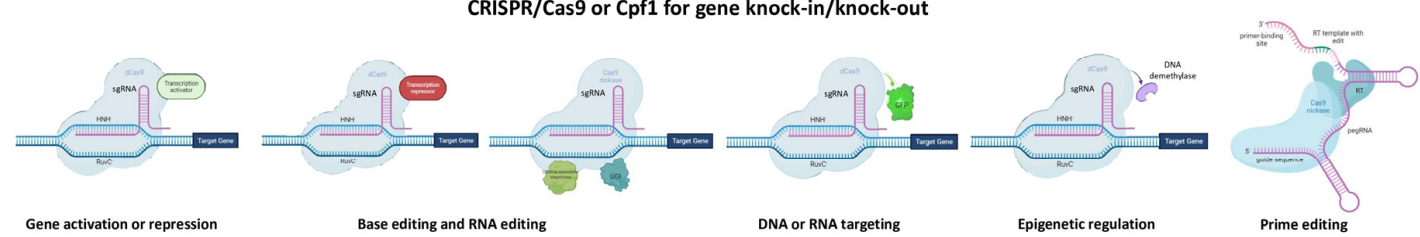

B

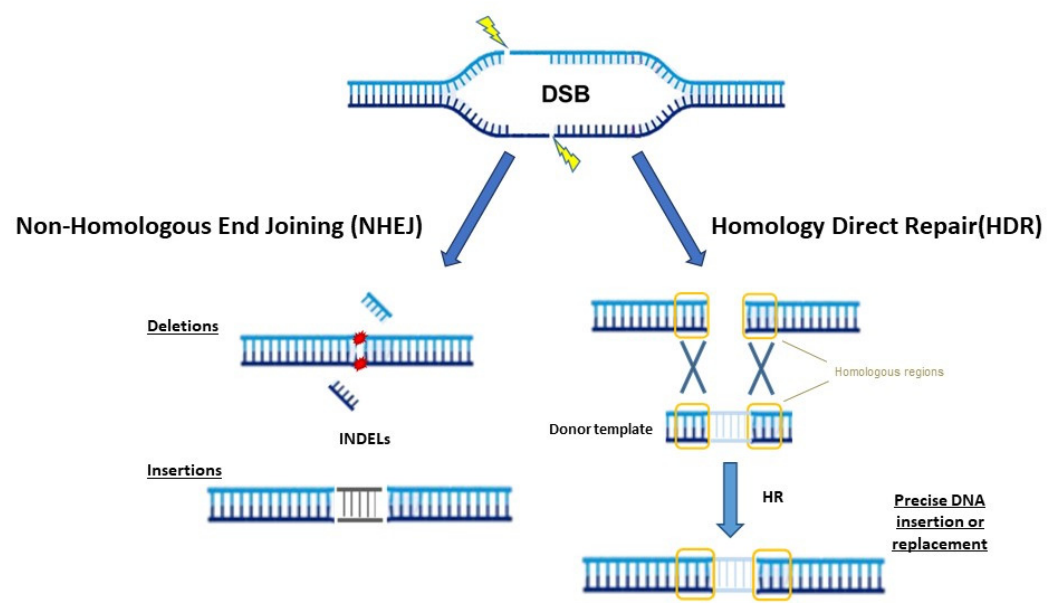

Figure 1. (A) Principal CRISPR/Cas9 or Cpf1 types of editing (top) and possible use for gene knockin or knock-out (bottom), synthetic-guide RNA (sgRNA), double-strand break (DSB), protospaceradjacent motif (PAM), reverse transcriptase (RT), uracil DNA glycosylase inhibitor (UGI), green fluorescent protein (GFP) and prime editing gRNA (pegRNA). (B) The two main DNA repair mechanisms and genetic mutations. 
The use of the CRISPR/Cas system as a genomic engineering tool occurred when Jinek et al., 2012 [4] (Figure 2) showed that the target DNA sequence could be reprogrammed simply using a chimeric synthetic-guide RNA (sgRNA), obtained by the fusion of crRNA and tracrRNA sequences and changing the 20 nucleotides of the crRNA that confer the targeting specificity. Once the Cas9 combined with the sgRNA recognizes the complementary spacer sequence adjacent to PAMs on double-strand DNA, genetic modifications are produced through the induction of DSB (Figure 1A), followed by the activation of DNA repair mechanisms (Figure 1B) through non-homologous end-joining (NHEJ) or homologous direct repair (HDR) [6-8].

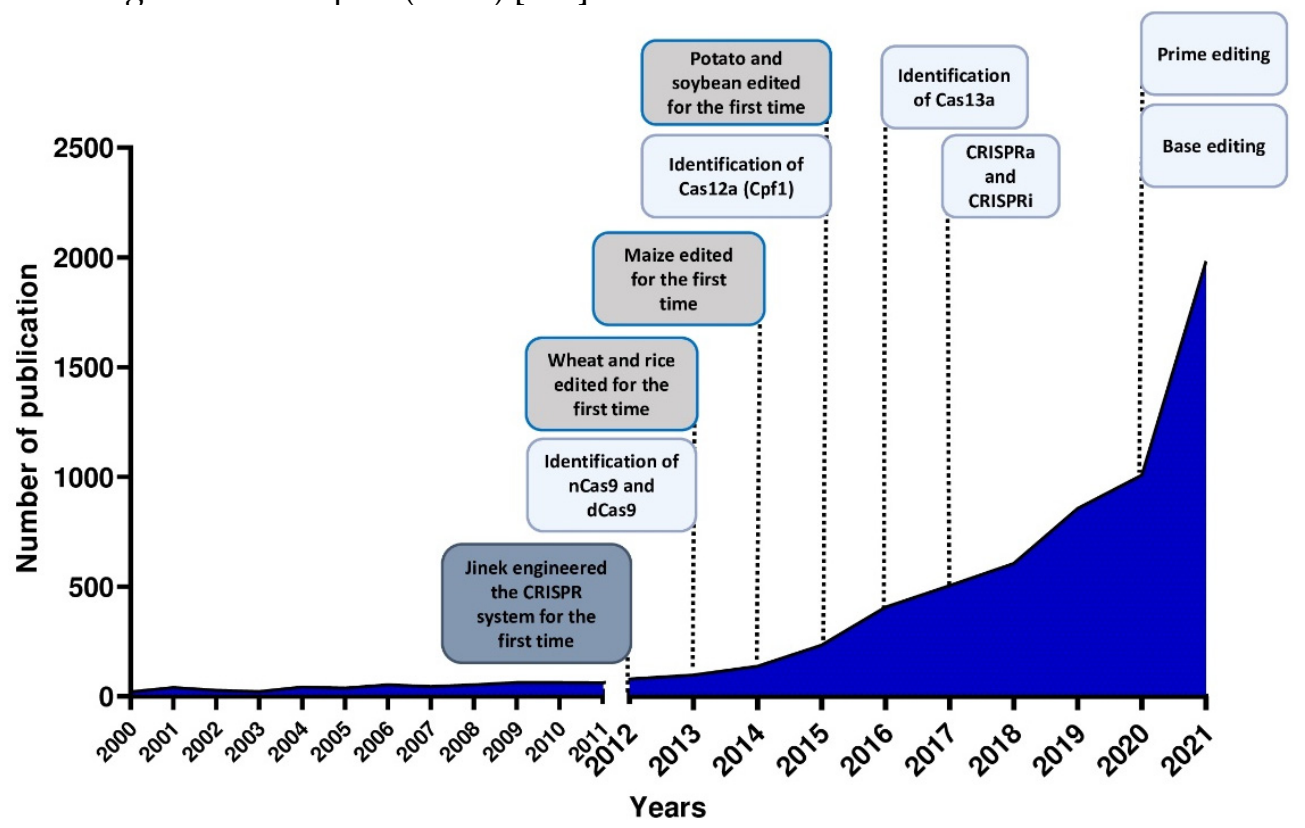

Figure 2. Number of publications in plant breeding using CRISPR systems and major achievements in the last 10 years.

\subsection{CRISPR Variants, Orthologs and Engineered Systems}

New types of Class II CRISPR/Cas systems are continuously found in bacteria, showing different features, and customized for use in plants (Figure 2). Several Cas9 orthologs, with different PAM specificities from other bacteria, have been discovered and some of them have already been applied for genome editing in model species [9]. Furthermore, it has been demonstrated that mutations in the PAM-interacting domains of wild-type $S p$ Cas9 could lead to SpCas9-engineered variants recognizing different PAM sequences [10], thus increasing the spectrum of editable target sites in the genome.

For example, Cas13a (C2c2) enzyme belongs to the Type VI Class II (Figure 1A). It is specialized in RNA recognition and cleavage, enabling its use in post-transcriptional repression, degradation of genetic material of RNA viruses and RNA binding [11]. Two studies have demonstrated the activity of Cas13a in rice protoplast to knock down endogenous genes and in Nicotiana benthamiana plants for interfering against RNA viruses [12,13]. Otherwise, the Cas12a (Cpf1) enzyme belongs to Class II Type V (Figure 1A) and differs from Cas9 in several important features: it recognizes the target region through PAM favoring AT-rich regions $\left(5^{\prime}-\mathrm{TTTN}^{\prime} 3^{\prime}\right)$, it cleaves the target sequence by producing DNA ends with a $5^{\prime}$ overhang and the crRNA directly functions as a guide RNA without the need for a complex with tracrRNA to be processed. This Cas protein has been used in many crop species [14] since its first application in rice and tobacco [15].

Furthermore, the Cas9 protein has been re-engineered through point mutations in RuvC and/or HNH nuclease domains, inactivating the catalytic activity of each domain (Figure 1A). It can be exploited to produce a nickase (nCas9) or a dead enzyme (dCas9) with complete loss of DNA cleavage activity. The nCas9 is usually used to enhance the specificity of CRISPR/Cas9, combining two nCas9 with pairs of sgRNAs that respectively cut only 
one DNA strand and therefore increase the number of recognized target bases. The dCas 9 protein can operate as cargo to load and deliver proteins with different functions to a specific target site. The use of inactive enzymes (nCas9 or dCas9) can also facilitate the directional introduction of DNA fragments at a specific site and the assembly of base and prime editors (discussed below). This enzyme has been employed in base editing as well as in genetic and epigenetic regulation of gene expression [16]. Otherwise, the most frequent use of $\mathrm{dCas} 9$ is in the activation (CRISPRa, activator) and repression (CRISPRi, interfering) of gene expression without introducing mutations in the genome (Figures $1 \mathrm{~A}$ and 2). Following this approach, the dCas9, guided by a sgRNA to a specific regulatory region, is fused to transcriptional modulators, which are generally transcriptional factors or protein domains recruiting key regulatory elements to control gene expression. Their use has been reported in plants both as activators [17-20] and as repressors [21,22]. The dCas9, associated with an acetyltransferase or a methyltransferase, can also act at the epigenetic level as CRISPRi and CRISPRa systems [23,24].

Both nCas9 and dCas9 are involved in the assembly of base editing and prime editing systems. Base editors, including cytosine base editors (CBEs) and adenosine base editors (ABEs), catalyze $\mathrm{C} / \mathrm{G}$ to $\mathrm{T} / \mathrm{A}$ or $\mathrm{A} / \mathrm{T}$ to $\mathrm{G} / \mathrm{C}$ transitions in DNA or RNA molecules (Figures 1A and 2). They have been optimized for plant genomes, providing high efficiency and precise editing at single base resolution [25]. Base editing systems have been applied in major crops such as wheat, rice, maize, tomato, potato, soybean and rapeseed [26,27]. Prime editing enables rewriting of genetic information into a specified DNA target site using a reverse transcriptase (RT) fused to a nickase enzyme and a prime editing guide RNA (pegRNA) to copy genetic information directly into the target genomic sequence (Figures 1A and 2) [28]. Although prime editing still needs to be improved for editing efficiency in plants, it has been applied to obtain precise modifications in rice, maize, potato and tomato [27-29], especially using the second generation of prime editors (PE2), in which an engineered RT with improved features (such as increased processivity, substrate affinity and inactivated RNase $\mathrm{H}$ activity) is fused to an nCas9 [28,30].

\subsection{New Perspectives for the Use of CRISPR/Cas System}

CRISPR opens many doors for plant breeders to boost breeding programs towards ambitious targets, thanks not only to the feasibility of its application in a wide range of crop species but also to its versatility as a genetic tool that is constantly evolving. The use of CRISPR-engineered systems can foster the generation of a wide range of heritable genetic mutations such as In/Dels, targeted insertions, point mutations and nucleotide substitutions that are the most frequent modifications obtained, as well as targeted chromosomal rearrangements and genetic or epigenetic control of gene expression (Figure 1A). In addition, it offers the advantage of decreasing off-targets and pleiotropic effects, without neglecting the possibility of obtaining transgene-free edited plants.

The possibility of producing transgene-free plants has been exploited through selfpollination and segregation of exogenous DNA [31], transiently expressing a plasmid vector encoding for Cas9 and gRNAs [32,33] or through the delivery of pre-assembled CRISPR/Cas9 ribonucleoproteins (RNPs) [34]. By delivering the Cas9 protein instead of the vector, there is no transfer of specific DNA from one species to another. In addition, the Cas9 protein remains inside the cells for three/five days and then is degraded, also reducing the off-target events. All together, these approaches will make CRISPR a useful tool for a new generation of plants that potentially do not fall within the scope of the current regulation process of genetically modified (GM) products.

Moreover, the discovery and the improvement of CRISPR as a precise genome editing tool has resulted in the establishment of several CRISPR-based companies that are hoping to capitalize on this new technology. Indeed, the potential of gene editing to address the 21st century's problems has taken hold in the agricultural industry and the list of CRISPR companies is growing each day. As an example, Synthetic Genomics ${ }^{\circledR}$ (https: / /www.viridos.com/, accessed on 17 November 2021) uses synthetic biology solutions to produce microalgae 
with higher levels of lipids to be used to address global sustainability problems. Plantedit ${ }^{\circledR}$ (https:/ / plantedit.com/, accessed on 17 November 2021) uses genome editing to generate modified soybean with a high oil content. Pairwise Plants (https:/ /www.pairwise.com/, accessed on 17 November 2021) is currently developing edited plants to assist farmers by providing them with new varieties of crops that require fewer resources to grow. Inari Agriculture $^{\circledR}$ (https://inari.com/, accessed on 17 November 2021) is using CRISPR to enhance plant breeding, by managing specific gene expression in plants, to develop customized seeds. Hudson River Biotechnology ${ }^{\circledR}$ (https:/ / www.hudsonriverbiotechnology. $\mathrm{com} /$, accessed on 17 November 2021) employs CRISPR technology to edit plants and microorganisms through a validated molecular breeding workflow called TiGER (Target identification, Guide selection, Entry into the cell and Regeneration). Yield10 ${ }^{\circledR}$ Bioscience (https: / / www.yield10bio.com/, accessed on 17 November 2021) aims to improve the yield of crops such as canola and soybeans, and also to increase the oil content of these and other oilseeds. Other relevant companies are Benson Hill Biosystems ${ }^{\circledR}$ (https:/ / bensonhill.com/, accessed on 17 November 2021), Corteva ${ }^{\circledR}$ (https:/ / www.corteva.com/, accessed on 17 November 2021) (agricultural division of DowDuPont), Syngenta ${ }^{\circledR}$ (https: //www.syngentagroup.com/, accessed on 17 November 2021) and Tropic Biosciences ${ }^{\circledR}$ (https:/ / www.tropicbioscience.com/, accessed on 17 November 2021).

Here, we focus on the recent advances in CRISPR technology for the improvement of the most cultivated crop species and its potential applications in synthetic biology (Figure 2), with particular regard to traits such as quality, yield and stress tolerance. Lastly, we report a quick focus on the global regulatory framework on GM plant legislation.

\section{Applications}

Since Jinek et al. (2012) [4] engineered for the first time the bacterial CRISPR system, it was not long before there was a demonstration of the application of CRISPR technology in plants [35-37], as shown by the increasing number of scientific publications that have been published during the last 10 years (Figure 2).

In 2013, as first crop species, rice was edited to disrupt the OsPDS and OsBADH2 genes by Shan and colleagues, and soon after Upadhyay et al. (2013) [38,39] used CRISPR/ Cas-mediated genome editing to target the inositol oxygenase (inox) and phytoene desaturase $(p d s)$ genes using a cell suspension culture of wheat. In maize, the ZmIPK gene was edited in protoplasts in 2014 [40]. Brooks et al. (2014) [41] produced tomato homozygous edited plants in $\mathrm{T}_{0}$ generation targeting the ARGONAUTE7 (SlAGO7) gene through CRISPR/Cas9.

Since then, many crop species have been edited by the CRISPR system. In 2015, two research groups applied CRISPR to edit potato genes $[42,43]$ and, in the same year, many scientific works reported genome modifications in soybean with CRISPR/ Cas9 [44-47]. Consequently, CRISPR became a powerful tool in crop breeding to improve several crop traits (Table 1), including yield, quality and safety, biotic- and abiotic-stress resistance, plant pharming and other applications in the field of medical plants [48].

Even if CRISPR has been widely used for various applications during the last 10 years (i.e., in enhancing both biotic and abiotic stress, improving yield performance and quality traits through biofortification), only a few genome-edited products are currently on the market [49]. 
Table 1. List of CRISPR applications in crop species. Plant species, targeted genes and resulting traits are reported for each field of application.

\begin{tabular}{|c|c|c|c|c|}
\hline Application & Plant Species & Target Genes & Resulting Traits & References \\
\hline Genetic Variability & $\begin{array}{l}\text { Rice } \\
\text { Pea } \\
\text { Tomato } \\
\text { Wheat }\end{array}$ & $\begin{array}{l}\text { Zep1 } \\
\text { RECQ4 } \\
\text { ZIP4-B2 }\end{array}$ & $\begin{array}{l}\text { Enhanced genetic recombination frequency } \\
\text { Increased crossover frequency } \\
\text { Enhanced recombination between homeologous chromosomes }\end{array}$ & $\begin{array}{l}{[50]} \\
{[51]} \\
{[52]}\end{array}$ \\
\hline Stress tolerance & $\begin{array}{l}\text { Rice } \\
\text { Maize } \\
\text { Wheat } \\
\text { Soybean } \\
\text { Potato } \\
\text { Tomato }\end{array}$ & $\begin{array}{l}\text { TIFY1b } \\
\text { ERF922 } \\
\text { eIF4G } \\
\text { Als2 } \\
\text { ARGOS8 } \\
\text { MLO } \\
\text { Qsd1 } \\
\text { F3H1, F3H2, FNSII-1 } \\
\text { ALS } \\
\text { RXLR effector gene Avr } 4 / 6 \\
\text { Mlo1 } \\
\text { ACET1a, ACET1b } \\
\text { MAPK3 }\end{array}$ & $\begin{array}{l}\text { Improved adaptation to low temperature } \\
\text { Improved resistance to rice blast } \\
\text { Improved resistance to rice tungro spherical virus } \\
\text { Chlorsulfuron-resistant maize } \\
\text { Improved resistance to drought } \\
\text { Enhanced resistance to powdery mildew } \\
\text { Longer dormancy } \\
\text { Increased isoflavone content and resistance to soybean mosaic virus } \\
\text { Development of glyphosate-resistant soybean } \\
\text { Enhanced tolerance to Phytophthora infestans } \\
\text { Reduced powdery mildew susceptibility } \\
\text { Increased resistance to Botrytis cinerea } \\
\text { Enhanced tolerance to heat stress }\end{array}$ & $\begin{array}{l}{[53]} \\
{[54]} \\
{[55]} \\
{[56]} \\
{[57]} \\
{[58]} \\
{[59]} \\
{[60]} \\
{[61]} \\
{[62]} \\
{[31]} \\
{[63]} \\
{[64]}\end{array}$ \\
\hline
\end{tabular}


Table 1. Cont.

\begin{tabular}{|c|c|c|c|c|}
\hline Application & Plant Species & Target Genes & Resulting Traits & References \\
\hline Quality & $\begin{array}{l}\text { Rice } \\
\text { Maize } \\
\text { Wheat } \\
\text { Potato } \\
\text { Sweet potato } \\
\text { Tomato } \\
\text { Barley } \\
\text { Rapeseed }\end{array}$ & $\begin{array}{l}\text { CrtI, PSY } \\
\text { GAD3 } \\
\text { SBEIIb, SBEI } \\
\text { GBSS } \\
\text { GBSS } \\
\text { IPK1 } \\
\text { SBEIIa } \\
\alpha \text {-gliadin genes } \\
\text { CM3, CM16 } \\
\text { ASN2 } \\
\text { SBEI } \\
\text { GBSS } \\
\text { SBEII } \\
\text { SGR1, LCY-E, Blc, LCY-B1, LCY-B2 } \\
\text { GAD2, GAD3 } \\
\text { GABA-Ts, SSADH } \\
\text { GBSS } \\
\text { D-hordein } \\
\text { ITPK }\end{array}$ & $\begin{array}{l}\text { High } \beta \text {-carotene content } \\
\text { High GABA content } \\
\text { High amylose content } \\
\text { Low amylose content } \\
\text { Low amylose content } \\
\text { Low phytic acid content } \\
\text { High amylose content } \\
\text { Low gluten content } \\
\text { Reduced amount of potential allergens } \\
\text { Reduced free asparagine } \\
\text { High amylose content } \\
\text { Low amylose content } \\
\text { High amylose content } \\
\text { High lycopene accumulation } \\
\text { High GABA content } \\
\text { High GABA content } \\
\text { Low amylose content } \\
\text { Reduced prolamine content and increased glutenin content } \\
\text { Low phytic acid content }\end{array}$ & $\begin{array}{l}{[33]} \\
{[74]} \\
{[75]} \\
{[76]} \\
{[77]} \\
{[78]} \\
{[79]} \\
{[80]} \\
{[81]} \\
{[82]} \\
{[83]} \\
{[84]} \\
{[84]} \\
{[85]} \\
{[86]} \\
{[87]} \\
{[88]} \\
{[89]} \\
{[90]}\end{array}$ \\
\hline Synthetic Biology & $\begin{array}{l}\text { Rice } \\
\text { Potato } \\
\text { Tomato } \\
\text { Barley } \\
\text { Arabidopsis } \\
\text { Switchgrass } \\
\text { Rapeseed } \\
\text { Salvia } \\
\text { Tobacco }\end{array}$ & $\begin{array}{l}\text { CrtI, PSY } \\
>\text { GBSS } \\
\text { PSY1 } \\
\text { CRTISO } \\
\text { COMT-1 } \\
\text { Chromosome 1, Chromosome } 2 \\
4 C L \\
\text { FAD2 } \\
\text { CPS1 } \\
\text { NtAn1 }\end{array}$ & $\begin{array}{l}\text { Insertion of large DNA fragments } \\
\text { Low amylose content } \\
\text { Inter-homologous somatic recombination } \\
\text { Inter-homologous somatic recombination } \\
\text { Increased bioethanol concentration of the mutant biomass } \\
\text { Reciprocal translocation } \\
\text { Used as lignocellulosic feedstock for bioenergy } \\
\text { Increased content of oleic acid } \\
\text { Customization of secondary metabolite profiles } \\
\text { Increased seed lipid accumulation for biodiesel production }\end{array}$ & $\begin{array}{l}{[33]} \\
{[91]} \\
{[92]} \\
{[93]} \\
{[94]} \\
{[95]} \\
{[96]} \\
{[97]} \\
{[98]} \\
{[99]}\end{array}$ \\
\hline
\end{tabular}




\subsection{Broadening Genetic Variability}

Crop breeding programmes generally rely on germplasm resources, the first source of genetic variation, essential to produce a progeny with suitable agronomic traits [100]. Considering that crop breeding programmes could take years due to the availability of beneficial alleles, several approaches have been developed during the last 40 years to face this problem [101]. In particular, non-naturally occurring alleles can be generated by the use of physical and chemical mutagenesis. At present, over 3000 commercial varieties of food crops have been produced by mutagenesis (IAEA Mutant Variety Database) [102]. Although the mutagenesis-based approach is important for broadening genetic variability in crops, it is time-consuming [103].

Due to their intrinsic potential, genome editing techniques, and in particular CRISPR/Cas9 systems, are currently being used in a precise and predictable way to introduce new genetic variability useful for the improvement of most cultivated crops [104,105]. In a few years, CRISPR demonstrated its ability to create variation in the gene pool, exploiting its core skills to produce gene knock-out or knock-in mutations, besides its ability to regulate gene expression at genetic and epigenetic levels. CRISPR has been used for introducing targeted single and multiple changes in plant genomes, allowing for the generation of mutants, including some genes that are difficult to access using traditional breeding.

A better understanding of the potential of the CRISPR/Cas arsenal and its potential epigenetic applications can lead to the generation of new genetic variability suitable for developing novel varieties with new allele combinations. Meiotic crossovers infrequently occur, limiting the production of new alleles and their combination into crops. In this context, the induction of crossover events between homologous or non-homologous chromosomal regions [106], manipulating meiotic recombination, can lead to broadening genetic variability $[107,108]$. An increase in crossover frequency has been achieved in plants through the editing of some genes that limit meiotic recombination. In particular, mutations in RecQ Like Helicase 4 (RECQ4) provoked an increase in crossovers in rice, pea and tomato [51]. Moreover, mutations of zeaxanthin epoxidase ZEP1 enhanced genetic recombination frequency in rice, as shown by Liu et al., 2021 [50]. In wheat, the ZIP4-B2 facilitates homologous recombination (HR) but inhibits crossovers between homeologous chromosomes. Martin and colleagues (2021) [52] obtained a mutant of ZIP4-B2 called zip4-ph1d that normally participates in $\mathrm{HR}$ but also allows recombination between homeologous chromosomes.

Indeed, these techniques represent an easier tool to introduce a novel wide range of desirable traits into cultivated crops [109-112].

\subsubsection{Enhancing Stress Tolerance}

Among the agricultural applications, several targets of CRISPR are related to the achievement of abiotic or biotic stress tolerance [113,114]. Generally, crop plants are able to overcome both biotic or abiotic stresses through changes that occur at the morphological, physiological, biochemical and molecular level [115]. However, the development of CRISPR may involve simple or complex mutations or the integration of specific genes in the target genome that may increase the breeding efficiency and the development of plant traits that were previously difficult to obtain $[111,115]$. Several crop species, including bacterialresistant banana and rice, fungus-resistant wheat and rice, drought-tolerant soybean, rice and maize, and salt-tolerant rice, have been studied using a gene-editing approach, and some of these are near the end of the research pipeline [111,116,117].

Among cultivated crops, rice (Oryza sativa L.) is the major food source for more than three billion people, and several studies using CRISPR are ongoing [39,118,119]. Many studies involving the use of the CRISPR/Cas9 technique for targeting multiple genes have been carried out [120-122]. Rice productivity is harshly limited due to the high concentration of salt in the soil that negatively affects plant growth and development, with negative consequences on the yield. In addition, diseases caused by biotic agents, including bacteria, fungi, viruses and insects, also negatively affect yield loss, leading to poor product quality [119]. As an example, the TIFY1b transcription factor is one of 
the cold tolerant genes in rice and its role was recently investigated in rice adaptation to low temperature through the CRISPR/Cas9 approach [53]. In 2019, researchers from the National Institute for Plant Biotechnology (NIPB) in New Delhi used CRISPR to study a rice able to withstand high concentrations of salt in soil [123]. In addition, Agrisea (https: / / www.agrisea.co.uk/, accessed on 17 November 2021), an ocean agriculture startup, developed a salt-tolerant rice that can be grown in salty ocean water without the use of soil, fertilizer or freshwater. Agrisea expects to have multiple modular floating mini-farms in the ocean by the end of 2021 and is already engaging in talks with major riceproducing and -consuming countries such as Vietnam, China and Bangladesh. However, Agrisea is waiting for the approval of both the Food and Drug Administration (FDA) and the US Department of Agriculture (USDA) to commercialize their salt-tolerant rice seeds. Moreover, the fungus Magnaporthe oryzae causes the most destructive disease in rice, known as rice blast, with up to $60-100 \%$ yield losses worldwide [124]. CRISPR/Cas9targeted knock-out of ERF transcription factor gene OsERF922 has demonstrated enhanced resistance to rice blast [54], suggesting that these kinds of approaches are promising for future targeted improvements. In fact, in 2018, CRISPR/Cas9-mediated editing produced rice plants resistant to the rice tungro spherical virus (RTSV) responsible of the rice tungro disease (RTD), producing the novel allele EIF4G [55]. Lastly, Colombian scientists from the International Center for Tropical Agriculture (CIAT) used CRISPR/Cas9 to confer resistance to rice hoja blanca virus (RHBV) and Xanthomonas oryzae [125].

Maize represents another largely used cereal crop, providing feed, food and fuel for more than 6000 million humans [126]. Maize grain yield is closely related to plant population density and could be affected by several factors, including water availability and soil fertility [127]. The first chlorsulfuron-resistant maize plants were developed by Svitashev et al. (2015) targeting the Als2 gene [56]. Recently, an application for a gene-edited maize that can tolerate water stress has been submitted to the Forestry and Agricultural Protection Division of the Agricultural and Livestock Service (SAG) [128]. In addition, in 2016, DuPont developed a drought-resistant maize using CRISPR [57] to edit the ARGOS8 locus, a negative regulator of the ethylene response. The field study showed that ARGOS8 variants had no yield loss under watered conditions [57]. Studies on maize that can withstand heat, UV radiation and drought are currently ongoing as field trials in Belgium, but only for research purposes (https://vib.be/news/permit-crispr-maizefield-trial-aims-measure-climate-stress, accessed on 17 November 2021). Furthermore, the Corteva Agri-Science and the International Maize and Wheat Improvement Center (CIMMYT) is developing maize varieties resistant to maize lethal necrosis (MLN), a viral disease that causes serious crop loss.

There are only few available studies for CRISPR techniques to address the major abiotic and biotic stresses in wheat compared to other cereal crops [129]. The first available CRISPRmediated approach was used to knock out the TaMLO, TaPDS and TaINOX genes [38,39]. Subsequent studies permitted the simultaneous knock-out of TaMLO homeoalleles, conferring resistance to powdery mildew in bread wheat [58]. Rain-resistant wheat was developed by researchers from the National Agriculture and Food Research Organization (NARO) and Okayama University in Japan [59] targeting the homeologous Qsd1 loci by the use of Agrobacterium-mediated CRISPR/Cas9.

Among cultivated crops, soybean (Glycine max (L.) Merr.) is a non-native and nonstaple crop in sub-Saharan Africa (SSA) with potential to be a commercial crop owing to its wide range of uses as food, feed and industrial raw material. Soybean low yield can be attributed to the use of poor-performing varieties and to the limited application of fertilizers and rhizobial inoculants in soils with no history of soybean production [130]. However, multiplex CRISPR/Cas9-mediated metabolic engineering was performed to increase soybean isoflavone content and resistance to soybean mosaic virus [60]. In addition, researchers from Universidad de la República and Instituto Nacional de Investigación Agropecuaria (INIA) used CRISPR to develop glyphosate-resistant soybean [61,128], while the Brazilian company Tropical Melhoramento \& Genética and the Israeli company Evogene 
collaborated to develop a soybean resistant to a plant nematode that destroys crops and decreases crop yields (https:/ / www.evogene.com/, accessed on 17 November 2021).

Among Solanaceae, potato (Solanum tuberosum L.) has tremendous significance due to its nutritional quality. Potato cultivation can be very challenging where there is erratic rain precipitation and water supply is scarce [131]. Due to its value, it remains worthwhile to develop biotic and abiotic stress-tolerant potatoes, considering that potato research is difficult due to the tetrasomic inheritance of cultivated potato. To date, a very limited number of studies have been reported in potato species using the CRISPR technology, and the majority were recently summarized by Dangol et al., 2019 [131]. The first edited potato was obtained in 2015 through the modification of the StIAA2 gene, as reported by Wang et al., 2015 [42]. Attempts have been made to establish a CRISPR/Cas9-mediated editing to generate potatoes tolerant of Phytophthora infestans, the oomycete responsible for potato late blight. Unfortunately, no mutagenized plants were detected in this study [62]. Moreover, Russian Academy of Sciences (RAS) institutes are developing gene-edited disease-resistant varieties of potatoes [132].

Tomato (Solanum lycopersicum L.), as one of the most cultivated vegetables and thanks to its aptitude for transformation and regeneration, lends itself to genetic modifications in order to facilitate the characterization of gene function, precision breeding and genetic improvement for resistance to biotic and abiotic stresses [133]. For example, the CRISPR/Cas9-induced mutation of SlMlo1 significantly reduced powdery mildew susceptibility, allowing for the generation of transgene-free powdery mildew-resistant tomato in less than 10 months [31]. Recently, CRISPR/Cas9-induced mutants of both tomato acetylenaseencoding genes $A C E T 1 a$ and $A C E T 1 b$ showed increased resistance to Botrytis cinerea [63]. Indeed, high temperatures are a major environmental stress that can limit plant growth and agricultural productivity. Chinese researchers focused on SIMAPK3, one of the genes involved in heat stress. In particular, CRISPR/Cas9-mediated slmapk3 mutants exhibited more tolerance to heat stress than wild-type plants, suggesting that SIMAPK3 was a negative regulator of thermotolerance [64].

Even if there is a multitude of studies regarding tomatoes, only few of them are at the end of the research pipeline. As an example, Nexgen Plants Pty Limited and University of Queensland produced gene-edited tomato allowing plants to detect and destroy the tomato spotted wilt virus and cauliflower mosaic virus. The USDA recently determined that the six tomato lines (NP-TV101-1, NP-TV101-2, NP-TV101-3, NP-TV201-1, NP-TV201-2 and NP-TV201-3) do not fall under the federal regulations for genetically engineered plants (https://www.isaaa.org/kc/cropbiotechupdate/article/default.asp?ID=17661, accessed on 17 November 2021).

\subsubsection{High Yield}

The impact of climate change and the need to satisfy dietary requirements due to rapid population growth are the main reasons for improving crop yield and food quality in a sustainable manner.

Crop yield is a complex trait influenced by polygenic regulation and the strong effect of environmental factors. For example, rice yield is determined by several traits such as the number of panicles per plant, the number of grains per panicle and grain weight and size. Several studies have shown that the expression of some genes negatively affects the yield and that their CRISPR/Cas9-mediated knock-out could have positive effects. To date, many genes including GN1a, DEP1, GS3, GW2, GW5, TGW6 in rice have been silenced using CRISPR/Cas9 technology with a significant increase in grain weight and size, grain number and dense and erect panicles $[65,66]$. Similarly, the knock-out of GW2, GW7 and GASR7 genes in hexaploid wheat resulted in an increase in seed size and weight [69-71,134]. In addition, maize kernel number per ear depends on inflorescence meristem controlled by the CLV-WUS feedback signaling pathway. Genome editing of cis-regulatory regions can adjust the expression level or pattern to enhance meristem activity and grain yield [68]. 
Similarly, the editing of the cis-regulatory element of the CLV-WUS pathway led to a larger fruit size in tomato [73].

To date, cultivars with improved yield obtained through the CRISPR/Cas system are not yet on the market. Despite this, a few studies have reached the trial stage. As an example, the simultaneous mutation of the PYL1, PYL4 and PYL6 genes improved growth and increased grain yield in rice. Phenotypic and agronomic analyses carried out on selected mutants, grown in the paddy fields of Shanghai and Lingshui County of Hainan Island under natural conditions, showed that the triple null pyl1/4/6 mutant had a $25-31 \%$ greater production compared to traditional varieties [67]. Furthermore, in a study conducted in China, the Chinese Academy of Sciences developed a soybean variety that can grow in warmer climates and is able to produce higher yields. Conversely, soybean crops planted in warmer climates generally have low yields due to early flowering and maturity. By silencing GmFT2a and GmFT5a through the CRISPR/Cas9 system, Cai and colleagues demonstrated that mutants flowered 31 days later and produced significantly increased numbers of pods and seeds per plant compared to the wild type [72].

In Japan, a research team from Tsukuba University used CRISPR/Cas9 to knock out two genes in rice in order to increase the grain number and size. In May 2017, the National Agriculture and Food Research Organization developed an experimental cultivation of rice with a higher yield trait obtained by CRISPR technology (Agricultural Biotechnology Annual_Tokyo_Japan_11-16-2017).

\subsubsection{Quality Improvement}

An important goal of genetic improvement concerns the nutritional quality of food. In fact, according to the World Health Organization (WHO, Geneva, Switzerland), malnutrition due to nutrient deficiency affects about 2 billion people worldwide, especially in underdeveloped and developing countries, leading to serious health, economic and social consequences (WHO, 2009).

In this context, vitamin A deficiency (VAD) is one of the major causes of malnutrition in the world and mainly affects children and pregnant women, causing several health complications such as vision damage, high susceptibility to infection, fetal malformations and neonatal death [135]. CRISPR/Cas9 genome editing has been successfully applied in rice and tomato using different strategies for carotenoid biofortification. In rice, the overexpression of $\mathrm{CrtI}$ and PSY led to marker-free mutants containing a good amount of $\beta$-carotene in dry weight [33], while in tomato the knock-out of five genes (SGR1, LCY-E, $B l c, L C Y-B 1$ and $L C Y-B 2)$ associated with the carotenoid metabolic pathway promoted the accumulation of lycopene, a bioactive component for treating chronic diseases and lowering the risk of cancer and cardiovascular diseases [85].

Another important example of biofortification concerns the increase in $\mathrm{X}$-aminobutyric acid (GABA). GABA is a non-proteinogenic amino acid inhibitory neurotransmitter effective in lowering blood pressure. The first study describing the application of the CRISPR/Cas9 system to increase GABA content in tomato fruits was carried out in Japan [86]. Through the mutation of the C-terminal region encoded by the SlGAD2 and SlGAD3 genes, GABA content was increased in leaves and fruits. In addition, $\mathrm{Li}$ and colleagues used a multiplex CRISPR/Cas9 system to knock out the SIGABA-Ts and SISSADH genes in tomato, obtaining a twenty-fold increase in GABA content [87]. In rice, by mutating the C-terminal of the OsGAD3 gene the GABA content increased seven-fold [74].

Phythic acid (PA) is the major phosphorus storage sink within the plant seed and, due to the lack of phytase in the digestive tract, is poorly digested by monogastric animals, including humans. PA is considered an anti-nutritional compound since it limits the bioavailability of phosphorus and minerals [136]. Low phytic acid (lpa) mutants were obtained in Brassica napus by silencing three functional paralogs of BnITPK gene. A 35\% decrease in phytic acid and a simultaneous increase in $P_{i}$ were found in the mutants [90]. Using CRISPR/Cas9 in common wheat, the disruption of TaIPK1.A led to an approxi- 
mately 1.5-to 2.1-fold increase in the Fe concentration and to a 1.6-to-1.9-fold rise in $\mathrm{Zn}$ concentration due to significant reduction in phytic acid content [78].

Free asparagine is the precursor for acrylamide formation during cooking and processing [137]. Acrylamide is classified as a Group 2a carcinogen by the International Agency for Research on Cancer (IARC). Since acrylamide in food potentially increases the risk of developing cancer, the reduction of free asparagine could lead to an improvement of food quality. The accumulation of free asparagine in wheat grain is responsive to environmental and crop management factors. By silencing TaASN2 through CRISPR/Cas9, Raffan and colleagues have demonstrated a more than $90 \%$ reduction in asparagine concentrations in the grain of edited wheat lines [82]. To date, the Department for Environment, Food \& Rural Affairs (DEFRA) has given permission for the first field trials of gene-edited wheat in the UK. Furthermore, Calyxt Inc. (Roseville, MN, USA) recently announced that it has completed the first field trial in Minnesota, Wisconsin and Michigan using a cold-storable potato. This potato does not produce acrylamide, typically generated when cold-stored potatoes are cooked.

Modifying the production and composition of carbohydrates in cereal crops represents an essential approach to improve the nutritional quality of the most important source of carbohydrates in human nutrition. In particular, cereals with a high content of amylose and resistant starch are interesting for the beneficial effects on human health and on the reduction of the risk of diet-related non-infectious chronic diseases [138]. Recently, the Chinese Academy of Sciences developed a transgene-free high amylose rice through CRISPR/Cas9mediated gene editing of SBEIIb and SBEI genes [75]. Similar results were obtained by silencing the SBEI and SBEII genes in potato and sweet potato, respectively [83,84]. In 2021, Li and colleagues [79] modified the starch composition, structure and properties through targeted mutagenesis of TaSBEIIa by CRISPR/Cas9 in winter and spring wheat varieties, generating transgene-free high-amylose wheat. Low amylose starch genotypes, defined as waxy genotypes producing essentially amylopectin, play an important role in the food and non-food industry. One single enzyme was found to be responsible for the synthesis of amylose, the granule-bound starch synthase (GBSS). Waxy genotypes were produced in several crops such as rice, maize, barley and potato $[76,77,84,88]$. Waxy potato was developed in Sweden using CRISPR/Cas9 technology, through transient transfection and regeneration from isolated protoplasts [91].

Proteins represent another important nutrient in many crop products. Their quantity and composition can affect the technological and nutritional quality of the derived foods. On the other hand, some proteins are undesirable because of their allergenicity and toxicity.

Several disorders are associated with the consumption of food products derived from wheat and other cereals. Gluten proteins, responsible for the technological properties of doughs, are also involved in triggering different pathologies such as celiac disease (CD) and wheat-dependent exercise-induced anaphylaxis (WDEIA) [139]. In 2018, the CRISPR/Cas9 technology was used to reduce $\alpha$-gliadins in wheat grain in order to obtain a low-gluten transgene-free wheat [80]. Structural and metabolic proteins, such as $\alpha$-amylase/trypsin inhibitors (ATI), are involved in the onset of wheat allergies and in non-celiac wheat sensitivity (NCWS) [140,141]. A CRISPR/Cas9 multiplexing strategy was used to edit the ATI subunits WTAI-CM3 and WTAI-CM16 in durum wheat with the aim of producing transgene-free wheat lines with reduced amounts of potential allergens involved in adverse reactions [81]. Lastly, in barley, the knock-out of the D-hordein gene leads to a considerable decrease in the prolamines and an increase in the glutenins, allowing for the modulation of gluten composition [89].

\subsection{Synthetic Biology}

In a broad definition, plant synthetic biology includes any re-designed plant species engineered to address specific targets by modifying, removing or introducing biological systems and components. According to this, all the achievements obtained by using CRISPR systems and discussed above could be referred to as synthetic biology approaches. 
Specifically, the definition given by the Engineering Biology Research Consortium (EBRC; www.ebrc.org, accessed on 17 November 2021) states that "the element that distinguishes synthetic biology from traditional molecular and cellular biology is the focus on the design and construction of core components (parts of enzymes, genetic circuits, metabolic pathways, etc.) that can be modelled, understood, and tuned to meet specific performance criteria ... to solve specific problems". Following this definition, synthetic biology often requires the introduction of complex DNA traits and elements for a new complete metabolic pathway or gene expression regulating system to provide the modified organism with new specific behavior.

CRISPR-mediated editing can certainly contribute to synthetic biology development. To date, not much has been done in crop species but many proofs have been reported in model plants regarding the construction of synthetic gene circuits via insertion of artificial DNA sequences or the modulation of metabolic pathways regulating gene expression. It has been shown that CRISPR systems can be used to induce chromosomal changes such as deletions, insertions and chromosome rearrangements [142-144].

Furthermore, it has been demonstrated that targeted insertion of large DNA fragments can be obtained through CRISPR editing, as was performed by Dong et al. (2020) [33] for the targeted insertion of a $5.2 \mathrm{~kb}$ carotenoid biosynthesis cassette at two pre-determined chromosomal regions in rice. In particular, these regions are known as genomic safe harbors (GSHs) that can accommodate transgenes without adverse effects on the host organism.

In addition, CRISPR can also mediate chromosome-engineering inducing crossovers and chromosomal rearrangements mediated by DSBs that favor HR between alleles of target genes $[107,108]$. Here, inter-homologous somatic recombination was induced by targeted induction of DSBs in the PHYTOENE SYNTHASE (PSY1) gene and Carotenoid isomerase (CRTISO) locus in tomato plants using the CRISPR/Cas9 system [92,93].

Frequently, parts of chromosomes do not participate in crossover due to the suppression of meiotic recombination caused by chromosome rearrangements, such as inversions and translocations. CRISPR can induce chromosomal rearrangements, including the induction or reversion of chromosomal inversions, useful for breaking or strengthening genetic linkages and inducing reciprocal translocations. Thanks to the introduction of multiple DSBs on the same chromosome or on heterologous chromosomes, CRISPR facilitates the possibility of inducing deletion and inversions or reciprocal translocation. Recently, Schwartz and colleagues [145] demonstrated the capability of CRISPR/Cas9 to mediate targeted $75.5-\mathrm{Mb}$ chromosomal inversion in maize, producing two DSBs, one on each side of the inversion. In 2020, Beying et al. [95] induced reciprocal translocation of about $1 \mathrm{Mb}$ in Arabidopsis thaliana between Chromosome 1 and 2. The target sites were located in intergenic regions, $0.5 \mathrm{Mb}$ from the end of the long arms of both chromosomes.

Furthermore, synthetic promoters and transcription factor engineering is becoming more and more useful in gene circuit design. These approaches lead to the production of specific compounds that could be used for industrial or medical purposes. In this context, CRISPR variants and orthologs represent the best way to act at the transcriptional or epigenetic level [146] and to fine-tune gene expression. To date, transcriptional regulation and epigenetic manipulation of plant genes have been reported in model plant species [147], demonstrating the wide potential of their application in crops. In addition, translation regulation mediated by the modification of upstream open reading frames (uORFs) is often used to regulate the translation of a specific protein [148]. Nucleotide insertions and deletions into the uORFs of genes involved in development and biosynthesis of antioxidants in Arabidopsis thaliana, lettuce and tomato have been reported by Zhang et al. (2018) [149].

All these achievements show the ability of CRISPR systems to easily overcome some limitations of plant synthetic biology such as the introduction of large DNA fragments, the manipulation of chromosome structure or the regulation of gene expression via genetic and epigenetic approaches.

Following plant biotechnology development, the use of plants as a bio-factory to produce biopolymers, biofuels and compounds for medical or industrial purposes cannot 
be separated from synthetic biology. One interesting application of CRISPR for the paper industry is the knock-out of the GBSS gene in potato to obtain amylopectin-enriched starch that is more suitable compared to amylase-enriched starch for paper manufacture [91].

Although climate change correlates with the consequence of arable land losses and the urgent need for sustainable production of foods, the constant fuel consumption severely affects biofuel demand. Oil seed crops with higher oil content and optimal fatty acid composition are required in order to breed new crops for biodiesel production. The modification of a fatty acid desaturase 2 (FAD2) gene, which encodes an enzyme that catalyzes the desaturation of oleic acid in Brassica napus, has been obtained using CRISPR/Cas9, determining an increase in the content of oleic acid of mutant plant seeds compared with oleic acid content of wild-type seeds [97]. Seed lipid accumulation increased in Nicotiana tabacum seeds through the knock-out of the NtAn1 transcription factor [99]. These tobacco plants are suitable for biodiesel production.

Moreover, the reduction of lignin content in biomass crops could be useful for a wide range of applications spanning from the paper and textile manufacture to the production of more digestible forage or biofuel production. In 2017, Park et al. [96] reported the reduction of lignin content obtained through the knock-out of the 4-coumarate: coenzyme A ligase (4CL) gene in perennial grass species switchgrass (Panicum virgatum), used as lignocellulosic feedstock for bioenergy. The mutant switchgrass plants showed reduced lignin and increased sugar release. In the 2020, Lee et al. [94] reduced the lignin content in barley through CRISPR editing of the caffeic acid O-methyltransferase 1 (COMT-1) gene, increasing significantly the bioethanol concentration of the mutant biomass.

Lastly, CRISPR-editing can also be used for the customization of secondary metabolite profiles in medical plants, as reported by Li et al., 2017 [98] in Salvia miltiorrhiza, a medicinal herb with significant pharmacological activities. The knock-out of the diterpene synthase (SmCPS1) gene, which is involved in the tanshinone biosynthesis pathway, blocks the metabolic flux to tanshinones, re-directing it towards other diterpene compounds that have the same precursor. In the field of plant-made pharmaceuticals, nicotine-free tobacco plants could be interesting for their use as platforms for the production of medical compounds, as reported by Schachtsiek in 2019 [150].

\section{Legislation Limits}

Since the release of the first genetically modified (GM) crops were established in the mid-1990s, a political and public debate has taken place. This debate has resulted in several regulations with the aim of ensuring the safety of the GMOs in order to achieve a high level of protection to humans, animals and environment. In general, GM crops are regulated at the country or regional level, generating a fragmented regulatory framework worldwide.

In particular, the United States has adopted the principle of substantial equivalence, establishing that GM products similar to commercialized ones should be considered conventional products.

Conversely, the GMO legislation of the European Union regulatory framework introduced the precautionary approach that was adopted as a guide in Directive 2001/18/EC.

Russia, in accordance with the amendments in Federal Law No. 358-FZ-2016, prohibited the cultivation of GM plants but not the imports of approved GM food and feed.

In addition, Canadian legislation distinguishes products on the basis of the novel traits considered and not on the basis of the technological approach.

A different approach was adopted in India, where the legislation is made on a case-bycase basis, while in Japan only products that do not contain inserted DNA or RNA are not considered as GMOs.

Lastly, Australia, New Zealand, Venezuela, Ecuador and Peru do not permit cultivation of GM crops while Brazil, Argentina and China are listed among the top five GM cultivating countries.

After more than 20 years of consumption of GM foods, no adverse effects on health or the environment have been found, and at present there is common agreement in the scien- 
tific community that an alternative regulatory system should be adopted, focusing on risk assessment of the trait/product rather than the technology used to produce it [112,151-153].

During the last years, with the development of the NBTs, the GMOs debate has been rekindled. Indeed, there are many concerns regarding regulation of these new techniques (Hartung and Schiemann, 2014). In particular, genome-editing approaches should overcome obstacles such as public acceptance of the technology and government regulatory policies [100,154], and some progress is already underway. As an example, in 2016 the USDA ruled that gene-edited plants without foreign DNA would not be considered GMOs and authorized the commercialization of DuPont Wx1 corn, which was produced to redirect the starch metabolic pathway towards amylopectin biosynthesis [34].

As recently recommended by the European Academies for Sciences applied to Agriculture, Food and Nature (UEAA, Union Européenne des Académies d'Agriculture, Paris, France) the GMO Directive approved in 2001 by the European Union is not appropriate because it was drafted before the discovery of NBTs. Thus, a new regulation frame taking into account the use of these methodologies to modify plant genomes in a precise manner is required.

Even if the European Court of Justice (ECJ) ruled that crops generated using genomeediting technologies be subjected to the above mentioned 2001/18/EC, the European Commission is expected to publish in the near future about the regulatory certainty of genome editing.

\section{Conclusions}

Crop breeding has been revolutionized by the development of CRISPR systems. Given their efficiency, simplicity and high specificity, genome editing approaches provided many advantages compared to traditional breeding. In contrast to transgenic approaches and mutagenesis, which lead to random insertions and to the production of unwanted phenotypes, genome-editing methods produce precise mutants, reducing off-targets and pleiotropic effects. Furthermore, interesting traits useful for boosting resilience to biotic and abiotic stress or affecting plant performance and the quality of derived foods have been introduced in plant genotypes, obtaining homozygous mutants in one or few generations; by contrast, classical breeding approaches require about 10 years to fix a mutation. CRISPR/Cas technology also represents an appropriate tool to produce transgene-free modified organisms. The transient expression of sgRNAs and Cas9, the segregation of sgRNA/Cas9 transgenes later in generations, or the use of ribonucleotide protein (RNP) complexes allow for obtaining transgene-free progeny with desired modifications.

Genome editing tools perfectly fit into the development of more sustainable agricultural systems. Through the development of edited crops with improved yield or with enhanced water use efficiency, they offer new ways to reach a greater production of foods with a high level of non-renewable resource saving (such as soil, energy and water). Moreover, many successful attempts have been reported to boost the resilience to heat and drought stresses that reduce crop productivity and undermine food security. As regards biotic stresses, GE crops could represent an opportunity to decrease the use of phytochemicals to both safeguard the environment and produce cost savings for farmers.

CRISPR-mediated editing is also a great opportunity for the improvement of plant synthetic biology. Some applications spanning from the performance improvement of crops and quality of food products to plant pharming can benefit from the versatility of CRISPR systems, which allows for introducing substantial modifications in chromosomes and modulating or producing synthetic gene circuits.

Hence, it is necessary to revise current legislation, especially in those countries with more restrictive rules, in order to avoid limiting the applications of genome editing techniques to the support of sustainable agriculture. In the near future, together with developing technologies, a science-based regulatory framework designed for edited crops and GMOs will need contributions from both scientists and policymakers to devise comprehensive plans for CRISPR-based approaches. 
Author Contributions: Conceptualization and writing-original draft preparation, F.C., A.F. and R.P.; writing-review and editing, F.C., A.F. and R.P.; supervision, F.C. All authors have read and agreed to the published version of the manuscript.

Funding: This research received no external funding.

Conflicts of Interest: The authors declare no conflict of interest.

Entry Link on the Encyclopedia Platform: https:/ / encyclopedia.pub/21321.

\section{References}

1. Doudna, J.A.; Charpentier, E. The New Frontier of Genome Engineering with CRISPR-Cas9. Science 2014, 80, 346. [CrossRef] [PubMed]

2. Fichtner, F.; Urrea Castellanos, R.; Ülker, B. Precision Genetic Modifications: A New Era in Molecular Biology and Crop Improvement. Planta 2014, 239, 921-939. [CrossRef]

3. Makarova, K.S.; Wolf, Y.I.; Alkhnbashi, O.S.; Costa, F.; Shah, S.A.; Saunders, S.J.; Barrangou, R.; Brouns, S.J.J.; Charpentier, E.; Haft, D.H.; et al. An Updated Evolutionary Classification of CRISPR-Cas Systems. Nat. Rev. Microbiol. 2015, 13, 722-736. [CrossRef] [PubMed]

4. Jinek, M.; Chylinski, K.; Fonfara, I.; Hauer, M.; Doudna, J.A.; Charpentier, E. A programmable dual-RNA-guided DNA endonuclease in adaptive bacterial immunity. Science 2012, 337, 816-822. [CrossRef]

5. Bortesi, L.; Fischer, R. The CRISPR/Cas9 System for Plant Genome Editing and Beyond. Biotechnol. Adv. 2015, 33, 41-52. [CrossRef]

6. Wyman, C.; Kanaar, R. DNA Double-Strand Break Repair: All's Well That Ends Well. Annu. Rev. Genet. 2006, 40, 363-383. [CrossRef]

7. Podevin, N.; Davies, H.V.; Hartung, F.; Nogué, F.; Casacuberta, J.M. Site-Directed Nucleases: A Paradigm Shift in Predictable, Knowledge-Based Plant Breeding. Trends Biotechnol. 2013, 31, 375-383. [CrossRef] [PubMed]

8. Chen, K.; Gao, C. Targeted Genome Modification Technologies and Their Applications in Crop Improvements. Plant Cell Rep. 2014, 33, 575-583. [CrossRef] [PubMed]

9. Hille, F.; Richter, H.; Wong, S.P.; Bratovič, M.; Ressel, S.; Charpentier, E. The Biology of CRISPR-Cas: Backward and Forward. Cell 2018, 172, 1239-1259. [CrossRef]

10. Montecillo, J.A.V.; Chu, L.L.; Bae, H. CRISPR-Cas9 System for Plant Genome Editing: Current Approaches and Emerging Developments. Agronomy 2020, 10, 1033. [CrossRef]

11. East-Seletsky, A.; O'Connell, M.R.; Knight, S.C.; Burstein, D.; Cate, J.H.D.; Tjian, R.; Doudna, J.A. Two Distinct RNase Activities of CRISPR-C2c2 Enable Guide-RNA Processing and RNA Detection. Nature 2016, 538, 270-273. [CrossRef] [PubMed]

12. Abudayyeh, O.O.; Gootenberg, J.S.; Essletzbichler, P.; Han, S.; Joung, J.; Belanto, J.J.; Verdine, V.; Cox, D.B.T.; Kellner, M.J.; Regev, A.; et al. RNA Targeting with CRISPR-Cas13. Nature 2017, 550, 280-284. [CrossRef] [PubMed]

13. Aman, R.; Ali, Z.; Butt, H.; Mahas, A.; Aljedaani, F.; Khan, M.Z.; Ding, S.; Mahfouz, M. RNA Virus Interference via CRISPR/Cas13a System in Plants. Genome Biol. 2018, 19, 1-9. [CrossRef] [PubMed]

14. Bandyopadhyay, A.; Kancharla, N.; Javalkote, V.S.; Dasgupta, S.; Brutnell, T.P. CRISPR-Cas12a (Cpf1): A Versatile Tool in the Plant Genome Editing Tool Box for Agricultural Advancement. Front. Plant Sci. 2020, 11, 1-17. [CrossRef]

15. Endo, A.; Masafumi, M.; Kaya, H.; Toki, S. Efficient Targeted Mutagenesis of Rice and Tobacco Genomes Using Cpf1 from Francisella Novicida. Sci. Rep. 2016, 6, 1-9. [CrossRef] [PubMed]

16. Moradpour, M.; Abdulah, S.N.A. CRISPR/DCas9 Platforms in Plants: Strategies and Applications beyond Genome Editing. Plant Biotechnol. J. 2020, 18, 32-44. [CrossRef]

17. Li, Z.; Zhang, D.; Xiong, X.; Yan, B.; Xie, W.; Sheen, J.; Li, J.F. A Potent Cas9-Derived Gene Activator for Plant and Mammalian Cells. Nat. Plants 2017, 3, 930-936. [CrossRef] [PubMed]

18. Lowder, L.G.; Zhou, J.; Zhang, Y.; Malzahn, A.; Zhong, Z.; Hsieh, T.F.; Voytas, D.F.; Zhang, Y.; Qi, Y. Robust Transcriptional Activation in Plants Using Multiplexed CRISPR-Act2.0 and MTALE-Act Systems. Mol. Plant 2018, 11, 245-256. [CrossRef]

19. Pan, C.; Wu, X.; Markel, K.; Malzahn, A.A.; Kundagrami, N.; Sretenovic, S.; Zhang, Y.; Cheng, Y.; Shih, P.M.; Qi, Y. CRISPR-Act3.0 for Highly Efficient Multiplexed Gene Activation in Plants. Nat. Plants 2021, 7, 942-953. [CrossRef]

20. Malzahn, A.; Zhang, Y.; Qi, Y. CRISPR-Act2.0: An Improved Multiplexed System for Plant Transcriptional Activation. In Plant Genome Editing with CRISPR Systems; Springer: Berlin/Heidelberg, Germany, 2019; pp. 83-93.

21. Piatek, A.A.; Lenaghan, S.C.; Neal Stewart, C. Advanced Editing of the Nuclear and Plastid Genomes in Plants. Plant Sci. 2018, 273, 42-49. [CrossRef] [PubMed]

22. Vazquez-Vilar, M.; Bernabé-Orts, J.M.; Fernandez-del-Carmen, A.; Ziarsolo, P.; Blanca, J.; Granell, A.; Orzaez, D. A Modular Toolbox for GRNA-Cas9 Genome Engineering in Plants Based on the GoldenBraid Standard. Plant Methods BioMed Cent. 2016, 12, 1-12. [CrossRef] [PubMed]

23. Lee, J.E.; Neumann, M.; Duro, D.I.; Schmid, M. CRISPR-Based Tools for Targeted Transcriptional and Epigenetic Regulation in Plants. PLoS ONE 2019, 14, 1-17. [CrossRef] [PubMed] 
24. Roca Paixão, J.F.; Gillet, F.X.; Ribeiro, T.P.; Bournaud, C.; Lourenço-Tessutti, I.T.; Noriega, D.D.; Melo, B.P.; de de Almeida-Engler, J.; Grossi-de-Sa, M.F. Improved Drought Stress Tolerance in Arabidopsis by CRISPR/DCas9 Fusion with a Histone AcetylTransferase. Sci. Rep. 2019, 9, 1-9. [CrossRef] [PubMed]

25. Zhu, H.; Li, C.; Gao, C. Applications of CRISPR-Cas in Agriculture and Plant Biotechnology. Nat. Rev. Mol. Cell Biol. 2020, 21, 661-677. [CrossRef] [PubMed]

26. Ren, Q.; Sretenovic, S.; Liu, G.; Zhong, Z.; Wang, J.; Huang, L.; Tang, X.; Guo, Y.; Liu, L.; Wu, Y.; et al. Improved Plant Cytosine Base Editors with High Editing Activity, Purity, and Specificity. Plant Biotechnol. J. 2021, 19, 2052-2068. [CrossRef] [PubMed]

27. Molla, K.A.; Sretenovic, S.; Bansal, K.C.; Qi, Y. Precise Plant Genome Editing Using Base Editors and Prime Editors. Nat. Plants 2021, 7, 1166-1187. [CrossRef] [PubMed]

28. Anzalone, A.V.; Randolph, P.B.; Davis, J.R.; Sousa, A.A.; Koblan, L.W.; Levy, J.M.; Chen, P.J.; Wilson, C.; Newby, G.A.; Raguram, A.; et al. Search-and-Replace Genome Editing without Double-Strand Breaks or Donor DNA. Nature 2019, 576, 149-157. [CrossRef] [PubMed]

29. Lin, Q.; Zong, Y.; Xue, C.; Wang, S.; Jin, S.; Zhu, Z.; Wang, Y.; Anzalone, A.V.; Raguram, A.; Doman, J.L.; et al. Prime Genome Editing in Rice and Wheat. Nat. Biotechnol. 2020, 38, 582-585. [CrossRef] [PubMed]

30. Xu, R.; Li, J.; Liu, X.; Shan, T.; Qin, R.; Wei, P. Development of Plant Prime-Editing Systems for Precise Genome Editing. Plant Commun. 2020, 1, 100043. [CrossRef]

31. Nekrasov, V.; Wang, C.; Win, J.; Lanz, C.; Weigel, D.; Kamoun, S. Rapid Generation of a Transgene-Free Powdery Mildew Resistant Tomato by Genome Deletion. Sci. Rep. 2017, 7, 1-6. [CrossRef]

32. Dong, O.X.; Yu, S.; Jain, R.; Zhang, N.; Duong, P.Q.; Butler, C.; Li, Y.; Lipzen, A.; Martin, J.A.; Barry, K.W.; et al. Marker-Free Carotenoid-Enriched Rice Generated through Targeted Gene Insertion Using CRISPR-Cas9. Nat. Commun. 2020, 11, 1-10. [CrossRef] [PubMed]

33. Waltz, E. Gene-Edited CRISPR Mushroom Escapes US Regulation. Nature 2016, 532, 293. [CrossRef] [PubMed]

34. Globus, R.; Qimron, U. A Technological and Regulatory Outlook on CRISPR Crop Editing. J. Cell. Biochem. 2018, 119, 1291-1298. [CrossRef] [PubMed]

35. Li, W.; Teng, F.; Li, T.; Zhou, Q. Simultaneous Generation and Germline Transmission of Multiple Gene Mutations in Rat Using CRISPR-Cas Systems. Nat. Biotechnol. 2013, 31, 684-686. [CrossRef] [PubMed]

36. Feng, Z.; Zhang, B.; Ding, W.; Liu, X.; Yang, D.L.; Wei, P.; Cao, F.; Zhu, S.; Zhang, F.; Mao, Y.; et al. Efficient Genome Editing in Plants Using a CRISPR/Cas System. Cell Res. 2013, 23, 1229-1232. [CrossRef]

37. Holton, N.; Nekrasov, V.; Ronald, P.C.; Zipfel, C. The Phylogenetically-Related Pattern Recognition Receptors EFR and XA21 Recruit Similar Immune Signaling Components in Monocots and Dicots. PLoS Pathog. 2015, 11, 1-22. [CrossRef]

38. Upadhyay, S.K.; Kumar, J.; Alok, A.; Tuli, R. RNA-Guided Genome Editing for Target Gene Mutations in Wheat. G3 Genes Genomes Genet. 2013, 3, 2233-2238. [CrossRef]

39. Shan, Q.; Wang, Y.; Li, J.; Gao, C. Genome Editing in Rice and Wheat Using the CRISPR/Cas System. Nat. Protoc. 2014, 9, 2395-2410. [CrossRef] [PubMed]

40. Liang, Z.; Zhang, K.; Chen, K.; Gao, C. Targeted Mutagenesis in Zea Mays Using TALENs and the CRISPR/Cas System. J. Genet. Genom. 2014, 41, 63-68. [CrossRef]

41. Brooks, C.; Nekrasov, V.; Lipppman, Z.B.; Van Eck, J. Efficient Gene Editing in Tomato in the First Generation Using the Clustered Regularly Interspaced Short Palindromic Repeats/CRISPR-Associated9 System. Plant Physiol. 2014, 166, 1292-1297. [CrossRef]

42. Wang, S.; Zhang, S.; Wang, W.; Xiong, X.; Meng, F.; Cui, X. Efficient Targeted Mutagenesis in Potato by the CRISPR/Cas9 System. Plant Cell Rep. 2015, 34, 1473-1476. [CrossRef]

43. Butler, N.M.; Atkins, P.A.; Voytas, D.F.; Douches, D.S. Generation and Inheritance of Targeted Mutations in Potato (Solanum tuberosum L.) Using the CRISPR/Cas System. PLoS ONE 2015, 10, 1-12. [CrossRef]

44. Michno, J.M.; Wang, X.; Liu, J.; Curtin, S.J.; Kono, T.J.; Stupar, R.M. CRISPR/Cas Mutagenesis of Soybean and Medicago Truncatula Using a New Web-Tool and a Modified Cas9 Enzyme. GM Crops Food 2015, 6, 243-252. [CrossRef] [PubMed]

45. Jacobs, T.B.; LaFayette, P.R.; Schmitz, R.J.; Parrott, W.A. Targeted Genome Modifications in Soybean with CRISPR/Cas9. BMC Biotechnol. 2015, 15, 1-10. [CrossRef]

46. Sun, X.; Hu, Z.; Chen, R.; Jiang, Q.; Song, G.; Zhang, H.; Xi, Y. Targeted Mutagenesis in Soybean Using the CRISPR-Cas9 System. Sci. Rep. 2015, 5, 1-10. [CrossRef] [PubMed]

47. Cai, Y.; Chen, L.; Liu, X.; Sun, S.; Wu, C.; Jiang, B.; Han, T.; Hou, W. CRISPR/Cas9-Mediated Genome Editing in Soybean Hairy Roots. PLoS ONE 2015, 10, 1-13. [CrossRef] [PubMed]

48. Dey, A. CRISPR/Cas Genome Editing to Optimize Pharmacologically Active Plant Natural Products. Pharmacol. Res. 2021, 164, 105359. [CrossRef]

49. Menz, J.; Modrzejewski, D.; Hartung, F.; Wilhelm, R.; Sprink, T. Genome Edited Crops Touch the Market: A View on the Global Development and Regulatory Environment. Front. Plant Sci. 2020, 11, 1-17. [CrossRef]

50. Liu, C.; Cao, Y.; Hua, Y.; Du, G.; Liu, Q.; Wei, X.; Sun, T.; Lin, J.; Wu, M.; Cheng, Z.; et al. Concurrent Disruption of Genetic Interference and Increase of Genetic Recombination Frequency in Hybrid Rice Using CRISPR/Cas9. Front. Plant Sci. 2021, 12, 757152. [CrossRef] [PubMed]

51. Mieulet, D.; Aubert, G.; Bres, C.; Klein, A.; Droc, G.; Vieille, E.; Rond-Coissieux, C.; Sanchez, M.; Dalmais, M.; Mauxion, J.P.; et al. Unleashing Meiotic Crossovers in Crops. Nat. Plants 2018, 4, 1010-1016. [CrossRef] [PubMed] 
52. Martín, A.C.; Alabdullah, A.K.; Moore, G. A Separation-of-Function ZIP4 Wheat Mutant Allows Crossover between Related Chromosomes and Is Meiotically Stable. Sci. Rep. 2021, 11, 1-13. [CrossRef] [PubMed]

53. Huang, X.; Zeng, X.; Li, J.; Zhao, D. Construction and Analysis of Tifyla and Tify1b Mutants in Rice (Oryza Sativa) Based on CRISPR/Cas9 Technology. J. Agric. Biotechnol. 2017, 25, 1003-1012.

54. Wang, F.; Wang, C.; Liu, P.; Lei, C.; Hao, W.; Gao, Y.; Liu, Y.G.; Zhao, K. Enhanced Rice Blast Resistance by CRISPR/Cas9-Targeted Mutagenesis of the ERF Transcription Factor Gene OsERF922. PLoS ONE 2016, 11, 1-18. [CrossRef] [PubMed]

55. Macovei, A.; Sevilla, N.R.; Cantos, C.; Jonson, G.B.; Slamet-Loedin, I.; Čermák, T.; Voytas, D.F.; Choi, I.R.; Chadha-Mohanty, P. Novel Alleles of Rice EIF4G Generated by CRISPR/Cas9-Targeted Mutagenesis Confer Resistance to Rice Tungro Spherical Virus. Plant Biotechnol. J. 2018, 16, 1918-1927. [CrossRef] [PubMed]

56. Svitashev, S.; Young, J.K.; Schwartz, C.; Gao, H.; Falco, S.C.; Cigan, A.M. Targeted Mutagenesis, Precise Gene Editing, and Site-Specific Gene Insertion in Maize Using Cas9 and Guide RNA. Plant Physiol. 2015, 169, 931-945. [CrossRef]

57. Shi, J.; Gao, H.; Wang, H.; Lafitte, H.R.; Archibald, R.L.; Yang, M.; Hakimi, S.M.; Mo, H.; Habben, J.E. ARGOS8 Variants Generated by CRISPR-Cas9 Improve Maize Grain Yield under Field Drought Stress Conditions. Plant Biotechnol. J. 2017, 15, 207-216. [CrossRef]

58. Wang, Y.; Cheng, X.; Shan, Q.; Zhang, Y.; Liu, J.; Gao, C.; Qiu, J.L. Simultaneous Editing of Three Homoeoalleles in Hexaploid Bread Wheat Confers Heritable Resistance to Powdery Mildew. Nat. Biotechnol. 2014, 32, 947-951. [CrossRef]

59. Abe, F.; Haque, E.; Hisano, H.; Tanaka, T.; Kamiya, Y.; Mikami, M.; Kawaura, K.; Endo, M.; Onishi, K.; Hayashi, T.; et al. Genome-Edited Triple-Recessive Mutation Alters Seed Dormancy in Wheat. Cell Rep. 2019, 28, 1362-1369.e4. [CrossRef]

60. Zhang, P.; Du, H.; Wang, J.; Pu, Y.; Yang, C.; Yan, R.; Yang, H.; Cheng, H.; Yu, D. Multiplex CRISPR/Cas9-Mediated Metabolic Engineering Increases Soya Bean Isoflavone Content and Resistance to Soya Bean Mosaic Virus. Plant Biotechnol. J. 2020, 18, 1384-1395. [CrossRef]

61. Dong, H.; Huang, Y.; Wang, K. The Development of Herbicide Resistance Crop Plants Using Crispr/Cas9-Mediated Gene Editing. Genes 2021, 12, 912. [CrossRef]

62. Fang, Y.; Tyler, B.M. Efficient Disruption and Replacement of an Effector Gene in the Oomycete Phytophthora Sojae Using CRISPR/Cas9. Mol. Plant Pathol. 2016, 17, 127-139. [CrossRef] [PubMed]

63. Jeon, J.E.; Kim, J.G.; Fischer, C.R.; Mehta, N.; Dufour-Schroif, C.; Wemmer, K.; Mudgett, M.B.; Sattely, E. A Pathogen-Responsive Gene Cluster for Highly Modified Fatty Acids in Tomato. Cell 2020, 180, 176-187.e19. [CrossRef] [PubMed]

64. Yu, W.; Wang, L.; Zhao, R.; Sheng, J.; Zhang, S.; Li, R.; Shen, L. Knockout of SIMAPK3 Enhances Tolerance to Heat Stress Involving ROS Homeostasis in Tomato Plants. BMC Plant Biol. 2019, 19, 1-13. [CrossRef] [PubMed]

65. Li, M.; Li, X.; Zhou, Z.; Wu, P.; Fang, M.; Pan, X.; Lin, Q.; Luo, W.; Wu, G.; Li, H. Reassessment of the Four Yield-Related Genes Gn1a, DEP1, GS3, and IPA1 in Rice Using a CRISPR/Cas9 System. Front. Plant Sci. 2016, 7, 1-13. [CrossRef]

66. Xu, R.; Yang, Y.; Qin, R.; Li, H.; Qiu, C.; Li, L.; Wei, P.; Yang, J. Rapid Improvement of Grain Weight via Highly Efficient CRISPR/Cas9-Mediated Multiplex Genome Editing in Rice. J. Genet. Genom. 2016, 43, 529-532. [CrossRef] [PubMed]

67. Miao, C.; Xiao, L.; Hua, K.; Zou, C.; Zhao, Y.; Bressan, R.A.; Zhu, J.K. Mutations in a Subfamily of Abscisic Acid Recepto Genes Promote Rice Growth and Productivity. Proc. Natl. Acad. Sci. USA 2018, 115, 6058-6063. [CrossRef]

68. Liu, L.; Gallagher, J.; Arevalo, E.D.; Chen, R.; Skopelitis, T.; Wu, Q.; Bartlett, M.; Jackson, D. Enhancing Grain-Yield-Related Traits by CRISPR-Cas9 Promoter Editing of Maize CLE Genes. Nat. Plants 2021, 7, 287-294. [CrossRef]

69. Wang, W.; Pan, Q.; He, F.; Akhunova, A.; Chao, S.; Trick, H.; Akhunov, E. Transgenerational CRISPR-Cas9 Activity Facilitates Multiplex Gene Editing in Allopolyploid Wheat. Cris. J. 2018, 1, 65-74. [CrossRef]

70. Zhang, Y.; Liang, Z.; Zong, Y.; Wang, Y.; Liu, J.; Chen, K.; Qiu, J.L.; Gao, C. Efficient and Transgene-Free Genome Editing in Wheat through Transient Expression of CRISPR/Cas9 DNA or RNA. Nat. Commun. 2016, 7, 1-8. [CrossRef]

71. Wang, W.; Pan, Q.; Tian, B.; He, F.; Chen, Y.; Bai, G.; Akhunova, A.; Trick, H.N.; Akhunov, E. Gene Editing of the Wheat Homologs of TONNEAU1-Recruiting Motif Encoding Gene Affects Grain Shape and Weight in Wheat. Plant J. 2019, 100, 251-264. [CrossRef]

72. Cai, Y.; Wang, L.; Chen, L.; Wu, T.; Liu, L.; Sun, S.; Wu, C.; Yao, W.; Jiang, B.; Yuan, S.; et al. Mutagenesis of GmFT2a and GmFT5a Mediated by CRISPR/Cas9 Contributes for Expanding the Regional Adaptability of Soybean. Plant Biotechnol. J. 2020, 18, 298-309. [CrossRef] [PubMed]

73. Rodríguez-Leal, D.; Lemmon, Z.H.; Man, J.; Bartlett, M.E.; Lippman, Z.B. Engineering Quantitative Trait Variation for Crop Improvement by Genome Editing. Cell 2017, 171, 470-480.e8. [CrossRef] [PubMed]

74. Akama, K.; Akter, N.; Endo, H.; Kanesaki, M.; Endo, M.; Toki, S. An In Vivo Targeted Deletion of the Calmodulin-Binding Domain from Rice Glutamate Decarboxylase 3 (OsGAD3) Increases $\gamma$-Aminobutyric Acid Content in Grains. Rice 2020, 13, 20. [CrossRef]

75. Sun, Y.; Jiao, G.; Liu, Z.; Zhang, X.; Li, J.; Guo, X.; Du, W.; Du, J.; Francis, F.; Zhao, Y.; et al. Generation of High-Amylose Rice through CRISPR/Cas9-Mediated Targeted Mutagenesis of Starch Branching Enzymes. Front. Plant Sci. 2021, 8, 1-15. [CrossRef]

76. Huang, L.; Li, Q.; Zhang, C.; Chu, R.; Gu, Z.; Tan, H.; Zhao, D.; Fan, X.; Liu, Q. Creating Novel Wx Alleles with Fine-Tuned Amylose Levels and Improved Grain Quality in Rice by Promoter Editing Using CRISPR/Cas9 System. Plant Biotechnol. J. 2020, 18, 2164-2166. [CrossRef] [PubMed]

77. Gao, H.; Gadlage, M.J.; Lafitte, H.R.; Lenderts, B.; Yang, M.; Schroder, M.; Farrell, J.; Snopek, K.; Peterson, D.; Feigenbutz, L.; et al. Superior Field Performance of Waxy Corn Engineered Using CRISPR-Cas9. Nat. Biotechnol. 2020, 38, 579-581. [CrossRef] 
78. Ibrahim, S.; Saleem, B.; Rehman, N.; Zafar, S.A.; Naeem, M.K.; Khan, M.R. CRISPR/Cas9 Mediated Disruption of Inositol Pentakisphosphate 2-Kinase 1 (TaIPK1) Reduces Phytic Acid and Improves Iron and Zinc Accumulation in Wheat Grains. J. Adv. Res. 2021, in press. [CrossRef]

79. Li, J.; Jiao, G.; Sun, Y.; Chen, J.; Zhong, Y.; Yan, L.; Jiang, D.; Ma, Y.; Xia, L. Modification of Starch Composition, Structure and Properties through Editing of TaSBEIIa in Both Winter and Spring Wheat Varieties by CRISPR/Cas9. Plant Biotechnol. J. 2021, 19, 937-951. [CrossRef]

80. Sánchez-León, S.; Gil-Humanes, J.; Ozuna, C.V.; Giménez, M.J.; Sousa, C.; Voytas, D.F.; Barro, F. Low-Gluten, Nontransgenic Wheat Engineered with CRISPR/Cas9. Plant Biotechnol. J. 2018, 16, 902-910. [CrossRef]

81. Camerlengo, F.; Frittelli, A.; Sparks, C.; Doherty, A.; Martignago, D.; Larré, C.; Lupi, R.; Sestili, F.; Masci, S. CRISPR-Cas9 Multiplex Editing of the $\alpha$-Amylase/Trypsin Inhibitor Genes to Reduce Allergen Proteins in Durum Wheat. Front. Sustain. Food Syst. 2020, 4, 104. [CrossRef]

82. Raffan, S.; Sparks, C.; Huttly, A.; Hyde, L.; Martignago, D.; Mead, A.; Hanley, S.J.; Wilkinson, P.A.; Barker, G.; Edwards, K.J.; et al. Wheat with Greatly Reduced Accumulation of Free Asparagine in the Grain, Produced by CRISPR/Cas9 Editing of Asparagine Synthetase Gene TaASN2. Plant Biotechnol. J. 2021, 19, 1602-1613. [CrossRef] [PubMed]

83. Tuncel, A.; Corbin, K.R.; Ahn-Jarvis, J.; Harris, S.; Hawkins, E.; Smedley, M.A.; Harwood, W.; Warren, F.J.; Patron, N.J.; Smith, A.M. Cas9-Mediated Mutagenesis of Potato Starch-Branching Enzymes Generates a Range of Tuber Starch Phenotypes. Plant Biotechnol. J. 2019, 17, 2259-2271. [CrossRef] [PubMed]

84. Wang, H.; Wu, Y.; Zhang, Y.; Yang, J.; Fan, W.; Zhang, H.; Zhao, S.; Yuan, L.; Zhang, P. CRISPR/Cas9-Based Mutagenesis of Starch Biosynthetic Genes in Sweet Potato (Ipomoea Batatas) for the Improvement of Starch Quality. Int. J. Mol. Sci. 2019, $20,4702$. [CrossRef] [PubMed]

85. Li, X.; Wang, Y.; Chen, S.; Tian, H.; Fu, D.; Zhu, B.; Luo, Y.; Zhu, H. Lycopene Is Enriched in Tomato Fruit by CRISPR/Cas9Mediated Multiplex Genome Editing. Front. Plant Sci. 2018, 9, 1-12. [CrossRef]

86. Nonaka, S.; Arai, C.; Takayama, M.; Matsukura, C.; Ezura, H. Efficient Increase of $\Gamma$-Aminobutyric Acid (GABA) Content in Tomato Fruits by Targeted Mutagenesis. Sci. Rep. 2017, 7, 1-14. [CrossRef]

87. Li, R.; Li, R.; Li, X.; Fu, D.; Zhu, B.; Tian, H.; Luo, Y.; Zhu, H. Multiplexed CRISPR/Cas9-Mediated Metabolic Engineering of $\gamma$-Aminobutyric Acid Levels in Solanum Lycopersicum. Plant Biotechnol. J. 2018, 16, 415-427. [CrossRef] [PubMed]

88. Zhong, Y.; Blennow, A.; Kofoed-Enevoldsen, O.; Jiang, D.; Hebelstrup, K.H. Protein Targeting to Starch 1 Is Essential for Starchy Endosperm Development in Barley. J. Exp. Bot. 2019, 70, 485-496. [CrossRef] [PubMed]

89. Yang, Q.; Zhong, X.; Li, Q.; Lan, J.; Tang, H.; Qi, P.; Ma, J.; Wang, J.; Chen, G.; Pu, Z.; et al. Mutation of the D-Hordein Gene by RNA-Guided Cas9 Targeted Editing Reducing the Grain Size and Changing Grain Compositions in Barley. Food Chem. 2020, 311, 125892. [CrossRef] [PubMed]

90. Sashidhar, N.; Harloff, H.J.; Potgieter, L.; Jung, C. Gene Editing of Three BnITPK Genes in Tetraploid Oilseed Rape Leads to Significant Reduction of Phytic Acid in Seeds. Plant Biotechnol. J. 2020, 18, 2241-2250. [CrossRef]

91. Andersson, M.; Turesson, H.; Nicolia, A.; Fält, A.S.; Samuelsson, M.; Hofvander, P. Efficient Targeted Multiallelic Mutagenesis in Tetraploid Potato (Solanum tuberosum) by Transient CRISPR-Cas9 Expression in Protoplasts. Plant Cell Rep. 2017, 36, 117-128. [CrossRef] [PubMed]

92. Hayut, S.F.; Bessudo, C.M.; Levy, A.A. Targeted Recombination between Homologous Chromosomes for Precise Breeding in Tomato. Nat. Commun. 2017, 8, 1-9. [CrossRef]

93. Shlush, I.; Ben Samach, A.; Melamed-Bessudo, C.; Ben-Tov, D.; Dahan-Meir, T.; Filler-Hayut, S.; Levy, A.A. Crispr/Cas9 Induced Somatic Recombination at the Crtiso Locus in Tomato. Forests 2021, 12, 59. [CrossRef]

94. Lee, J.H.; Won, H.J.; Hoang Nguyen Tran, P.; Lee, S.M.; Kim, H.Y.; Jung, J.H. Improving Lignocellulosic Biofuel Production by CRISPR/Cas9-mediated Lignin Modification in Barley. GCB Bioenergy 2021, 13, 742-752. [CrossRef]

95. Beying, N.; Schmidt, C.; Pacher, M.; Houben, A.; Puchta, H. CRISPR-Cas9-Mediated Induction of Heritable Chromosomal Translocations in Arabidopsis. Nat. Plants 2020, 6, 638-645. [CrossRef] [PubMed]

96. Park, J.J.; Yoo, C.G.; Flanagan, A.; Pu, Y.; Debnath, S.; Ge, Y.; Ragauskas, A.J.; Wang, Z.Y. Defined Tetra-Allelic Gene Disruption of the 4-Coumarate:Coenzyme A Ligase 1 (Pv4CL1) Gene by CRISPR/Cas9 in Switchgrass Results in Lignin Reduction and Improved Sugar Release Mike Himmel. Biotechnol. Biofuels BioMed Cent. 2017, 10, 1-11. [CrossRef] [PubMed]

97. Okuzaki, A.; Ogawa, T.; Koizuka, C.; Kaneko, K.; Inaba, M.; Imamura, J.; Koizuka, N. CRISPR/Cas9-Mediated Genome Editing of the Fatty Acid Desaturase 2 Gene in Brassica Napus. Plant Physiol. Biochem. 2018, 131, 63-69. [CrossRef] [PubMed]

98. Li, B.; Cui, G.; Shen, G.; Zhan, Z.; Huang, L.; Chen, J.; Qi, X. Targeted Mutagenesis in the Medicinal Plant Salvia Miltiorrhiza. Sci. Rep. 2017, 7, 1-9. [CrossRef] [PubMed]

99. Tian, Y.; Liu, X.; Fan, C.; Li, T.; Qin, H.; Li, X.; Chen, K.; Zheng, Y.; Chen, F.; Xu, Y. Enhancement of Tobacco (Nicotiana Tabacum L.) Seed Lipid Content for Biodiesel Production by CRISPR-Cas9-Mediated Knockout of NtAn1. Front. Plant Sci. 2021, 11, 1-13. [CrossRef] [PubMed]

100. Hua, K.; Zhang, J.; Botella, J.R.; Ma, C.; Kong, F.; Liu, B.; Zhu, J.K. Perspectives on the Application of Genome-Editing Technologies in Crop Breeding. Mol. Plant 2019, 12, 1047-1059. [CrossRef] [PubMed]

101. Oladosu, Y.; Rafii, M.Y.; Abdullah, N.; Hussin, G.; Ramli, A.; Rahim, H.A.; Miah, G.; Usman, M. Principle and Application of Plant Mutagenesis in Crop Improvement: A Review. Biotechnol. Biotechnol. Equip. 2016, 30, 1-16. [CrossRef] 
102. Chaudhary, J.; Deshmukh, R.; Sonah, H. Mutagenesis Approaches and Their Role in Crop Improvement. Plants 2019, 8, 467. [CrossRef]

103. Raina, A.; Laskar, R.; Khursheed, S.; Amin, R.; Tantray, Y.; Parveen, K.; Khan, S. Role of Mutation Breeding in Crop ImprovementPast, Present and Future. Asian Res. J. Agric. 2016, 2, 1-13. [CrossRef]

104. Sharma, S.; Kaur, R.; Singh, A. Recent Advances in CRISPR/Cas Mediated Genome Editing for Crop Improvement. Plant Biotechnol. Rep. 2017, 11, 193-207. [CrossRef]

105. Aglawe, S.B.; Barbadikar, K.M.; Mangrauthia, S.K.; Madhav, M.S. New Breeding Technique "Genome Editing” for Crop Improvement: Applications, Potentials and Challenges. Biotech 2018, 8, 1-20. [CrossRef] [PubMed]

106. Filler-hayut, S.; Kniazev, K.; Melamed-bessudo, C.; Levy, A.A. Targeted Inter-Homologs Recombination in Arabidopsis Euchromatin and Heterochromatin. Int. J. Mol. Sci. 2021, 22, 12096. [CrossRef] [PubMed]

107. Taagen, E.; Bogdanove, A.J.; Sorrells, M.E. Counting on Crossovers: Controlled Recombination for Plant Breeding. Trends Plant Sci. 2020, 25, 455-465. [CrossRef] [PubMed]

108. Blary, A.; Jenczewski, E. Manipulation of Crossover Frequency and Distribution for Plant Breeding. Theor. Appl. Genet. 2019, 132, 575-592. [CrossRef]

109. Schaart, J.G.; van de Wiel, C.C.M.; Lotz, L.A.P.; Smulders, M.J.M. Opportunities for Products of New Plant Breeding Techniques. Trends Plant Sci. 2016, 21, 438-449. [CrossRef] [PubMed]

110. Ahmar, S.; Gill, R.A.; Jung, K.H.; Faheem, A.; Qasim, M.U.; Mubeen, M.; Zhou, W. Conventional and Molecular Techniques from Simple Breeding to Speed Breeding in Crop Plants: Recent Advances and Future Outlook. Int. J. Mol. Sci. 2020, $21,2590$. [CrossRef] [PubMed]

111. Qaim, M. Role of New Plant Breeding Technologies for Food Security and Sustainable Agricultural Development. Appl. Econ. Perspect. Policy 2020, 42, 129-150. [CrossRef]

112. Hartung, F.; Schiemann, J. Precise Plant Breeding Using New Genome Editing Techniques: Opportunities, Safety and Regulation in the EU. Plant J. 2014, 78, 742-752. [CrossRef] [PubMed]

113. Ahmad, P.; Abdel Latef, A.A.H.; Rasool, S.; Akram, N.A.; Ashraf, M.; Gucel, S. Role of Proteomics in Crop Stress Tolerance. Front. Plant Sci. 2016, 7, 1-14. [CrossRef] [PubMed]

114. Hussain, B. Modernization in Plant Breeding Approaches for Improving Biotic Stress Resistance in Crop Plants. Turkish. J. Agric. For. 2015, 39, 515-530. [CrossRef]

115. Bigini, V.; Camerlengo, F.; Botticella, E.; Sestili, F.; Savatin, D.V. Biotechnological Resources to Increase Disease-Resistance by Improving Plant Immunity: A Sustainable Approach to Save Cereal Crop Production. Plants 2021, 10, 1146. [CrossRef]

116. Hickey, L.T.; Hafeez, A.N.; Robinson, H.; Jackson, S.A.; Leal-Bertioli, S.C.M.; Tester, M.; Gao, C.; Godwin, I.D.; Hayes, B.J.; Wulff, B.B.H. Breeding Crops to Feed 10 Billion. Nat. Biotechnol. 2019, 37, 744-754. [CrossRef]

117. Shan-e-Ali Zaidi, S.; Vanderschuren, H.; Qaim, M.; Mahfouz, M.M.; Kohli, A.; Mansoor, S.; Tester, M. New Plant Breeding Technologies for Food Security. Science 2019, 363, 1390-1391. [CrossRef] [PubMed]

118. Hu, X.; Meng, X.; Liu, Q.; Li, J.; Wang, K. Increasing the Efficiency of CRISPR-Cas9-VQR Precise Genome Editing in Rice. Plant Biotechnol. J. 2018, 16, 292-297. [CrossRef] [PubMed]

119. Mishra, R.; Joshi, R.K.; Zhao, K. Genome Editing in Rice: Recent Advances, Challenges, and Future Implications. Front. Plant Sci. 2018, 9, 1361. [CrossRef] [PubMed]

120. Jiang, W.; Zhou, H.; Bi, H.; Fromm, M.; Yang, B.; Weeks, D.P. Demonstration of CRISPR/Cas9/SgRNA-Mediated Targeted Gene Modification in Arabidopsis, Tobacco, Sorghum and Rice. Nucleic Acids Res. 2013, 41, 1-12. [CrossRef]

121. Miao, J.; Guo, D.; Zhang, J.; Huang, Q.; Qin, G.; Zhang, X.; Wan, J.; Gu, H.; Qu, L.J. Targeted Mutagenesis in Rice Using CRISPR-Cas System. Cell Res. 2013, 23, 1233-1236. [CrossRef]

122. Xie, K.; Yang, Y. RNA-Guided Genome Editing in Plants Using a CRISPR-Cas System. Mol. Plant 2013, 6, 1975-1983. [CrossRef] [PubMed]

123. Farhat, S.; Jain, N.; Singh, N.; Sreevathsa, R.; Dash, P.K.; Rai, R.; Yadav, S.; Kumar, P.; Sarkar, A.K.; Jain, A.; et al. CRISPR-Cas9 Directed Genome Engineering for Enhancing Salt Stress Tolerance in Rice. Semin. Cell Dev. Biol. 2019, 96, 91-99. [CrossRef] [PubMed]

124. Kihoro, J.; Bosco, N.J.; Murage, H.; Ateka, E.; Makihara, D. Investigating the Impact of Rice Blast Disease on the Livelihood of the Local Farmers in Greater Mwea Region of Kenya. Springerplus 2013, 2, 1-13. [CrossRef]

125. Sánchez, F.J.; Arciniegas, J.P.; Brand, A.; Vacca, O.; Tohme, J.; Becerra, L.A. E Dición de Genomas En Manihot Esculenta Crantz Para La Producción de Plantas Waxy y Para La Resistencia a La Bacteriosis Vascular Producida Por Xanthomonas Axonopodis P. In Proceedings of the X Encuentro Latinoamericano y Del Caribe de Biotecnología Agropecuaria y XI Simposio REDBIO Argentina, Montevideo, Uruguay, 12-15 November 2019. [CrossRef]

126. Tokatlidis, I.S. Adapting Maize Crop to Climate Change. Agron. Sustain. Dev. 2013, 33, 63-79. [CrossRef]

127. Sangoi, L.; Gracietti, M.A.; Rampazzo, C.; Bianchetti, P. Response of Brazilian Maize Hybrids from Different Eras to Changes in Plant Density. F Crop. Res. 2002, 79, 39-51. [CrossRef]

128. Gatica-Arias, A. The Regulatory Current Status of Plant Breeding Technologies in Some Latin American and the Caribbean Countries. Plant Cell. Tissue Organ Cult. 2020, 141, 229-242. [CrossRef]

129. Kumar, R.; Kaur, A.; Pandey, A.; Mamrutha, H.M.; Singh, G.P. CRISPR-Based Genome Editing in Wheat: A Comprehensive Review and Future Prospects. Mol. Biol. Rep. 2019, 46, 3557-3569. [CrossRef] 
130. Khojely, D.M.; Ibrahim, S.E.; Sapey, E.; Han, T. History, Current Status, and Prospects of Soybean Production and Research in Sub-Saharan Africa. Crop J. 2018, 6, 226-235. [CrossRef]

131. Das Dangol, S.; Barakate, A.; Stephens, J.; Çalıskan, M.E.; Bakhsh, A. Genome Editing of Potato Using CRISPR Technologies: Current Development and Future Prospective. Plant Cell. Tissue Organ Cult. 2019, 139, 403-416. [CrossRef]

132. Dobrovidova, O. Russia Joins in Global Gene-Editing Bonanza. Nature 2019, 569, 319-320. [CrossRef]

133. Xia, X.; Cheng, X.; Li, R.; Yao, J.; Li, Z.; Cheng, Y. Advances in Application of Genome Editing in Tomato and Recent Development of Genome Editing Technology. Theor. Appl. Genet. 2021, 134, 2727-2747. [CrossRef] [PubMed]

134. Wang, J.; Zhou, L.; Shi, H.; Chern, M.; Yu, H.; Yi, H.; He, M.; Yin, J.; Zhu, X.; Li, Y.; et al. A Single Transcription Factor Promotes Both Yield and Immunity in Rice. Science 2018, 361, 1026-1028. [CrossRef] [PubMed]

135. Sommer, A. Vitamin A Deficiency and Clinical Disease: An Historical Overview. J. Nutr. 2008, 138, 1835-1839. [CrossRef]

136. Sparvoli, F.; Cominelli, E. Seed Biofortification and Phytic Acid Reduction: A Conflict of Interest for the Plant? Plants 2015, 4, 728-755. [CrossRef]

137. Mottram, D.S.; Wedzicha, B.L.; Dodson, A.T. Food Chemistry: Acrylamide Is Formed in the Maillard Reaction. Nature 2002, 419, 448-449. [CrossRef]

138. Regina, A.; Bird, A.; Topping, D.; Bowden, S.; Freeman, J.; Barsby, T.; Kosar-Hashemi, B.; Li, Z.; Rahman, S.; Morell, M. HighAmylose Wheat Generated by RNA Interference Improves Indices of Large-Bowel Health in Rats. Proc. Natl. Acad. Sci. USA 2006, 103, 3546-3551. [CrossRef]

139. Tatham, A.S.; Shewry, P.R. Allergens to Wheat and Related Cereals. Clin. Exp. Allergy 2008, 38, 1712-1726. [CrossRef]

140. Mansueto, P.; Soresi, M.; Iacobucci, R.; La Blasca, F.; Romano, G.; D’Alcamo, A.; Carroccio, A. Non-Celiac Wheat Sensitivity: A Search for the Pathogenesis of a Self-Reported Condition. Ital. J. Med. 2019, 13, 15-23. [CrossRef]

141. Geisslitz, S.; Shewry, P.; Brouns, F.; America, A.H.P.; Caio, G.P.I.; Daly, M.; D’Amico, S.; De Giorgio, R.; Gilissen, L.; Grausgruber, H.; et al. Wheat ATIs: Characteristics and Role in Human Disease. Front. Nutr. 2021, 8, 1-16. [CrossRef]

142. Schmidt, C.; Schindele, P.; Puchta, H. From Gene Editing to Genome Engineering: Restructuring Plant Chromosomes via CRISPR/Cas. aBiotech 2020, 1, 21-31. [CrossRef]

143. Schindele, A.; Dorn, A.; Puchta, H. CRISPR/Cas Brings Plant Biology and Breeding into the Fast Lane. Curr. Opin. Biotechnol. 2020, 61, 7-14. [CrossRef]

144. Zhou, H.; Liu, B.; Weeks, D.P.; Spalding, M.H.; Yang, B. Large Chromosomal Deletions and Heritable Small Genetic Changes Induced by CRISPR/Cas9 in Rice. Nucleic Acids Res. 2014, 42, 10903-10914. [CrossRef] [PubMed]

145. Schwartz, C.; Lenderts, B.; Feigenbutz, L.; Barone, P.; Llaca, V.; Fengler, K.; Svitashev, S. CRISPR-Cas9-mediated 75.5-Mb inversion in maize. Nat. Plants 2020, 6, 1427-1431. [CrossRef]

146. Huang, D.; Kosentka, P.Z.; Liu, W. Synthetic Biology Approaches in Regulation of Targeted Gene Expression. Curr. Opin. Plant Biol. 2021, 63, 102036. [CrossRef]

147. Karlson, C.K.S.; Mohd-noor, S.N.; Nolte, N.; Tan, B.C. Crispr/Dcas9-based Systems: Mechanisms and Applications in Plant Sciences. Plants 2021, 10, 2055. [CrossRef] [PubMed]

148. Si, X.; Zhang, H.; Wang, Y.; Chen, K.; Gao, C. Manipulating Gene Translation in Plants by CRISPR-Cas9-Mediated Genome Editing of Upstream Open Reading Frames. Nat. Protoc. 2020, 15, 338-363. [CrossRef] [PubMed]

149. Zhang, H.; Si, X.; Ji, X.; Fan, R.; Liu, J.; Chen, K.; Wang, D.; Gao, C. Genome Editing of Upstream Open Reading Frames Enables Translational Control in Plants. Nat. Biotechnol. 2018, 36, 894-900. [CrossRef]

150. Schachtsiek, J.; Stehle, F. Nicotine-Free, Nontransgenic Tobacco (Nicotiana Tabacum 1.) Edited by CRISPR-Cas9. Plant Biotechnol. J. 2019, 17, 2228-2230. [CrossRef]

151. Morris, S.H.; Spillane, C. GM Directive Deficiencies in the European Union. The Current Framework for Regulating GM Crops in the EU Weakens the Precautionary Principle as a Policy Tool. EMBO Rep. 2008, 9, 500-504. [CrossRef]

152. Podevin, N.; Devos, Y.; Davies, H.V.; Nielsen, K.M. Transgenic or Not? No Simple Answer! New Biotechnology-Based Plant Breeding Techniques and the Regulatory Landscape. EMBO Rep. 2012, 13, 1057-1061. [CrossRef]

153. Heap, B. Europe Should Rethink Its Stance on GM Crops. Nature 2013, 498, 409. [CrossRef]

154. Khatodia, S.; Bhatotia, K.; Passricha, N.; Khurana, S.M.P.; Tuteja, N. The CRISPR/Cas Genome-Editing Tool: Application in Improvement of Crops. Front. Plant Sci. 2016, 7, 1-13. [CrossRef] [PubMed] 